\title{
Phylogeny of Thripophagini ovenbirds (Aves: Synallaxinae: Furnariidae)
}

\author{
ESTHER QUINTERO ${ }^{1,2 *,}$ and UTKU PERKTAŞŞ,3,॰ \\ ${ }^{1}$ Department of Ornithology, American Museum of Natural History, Central Park West at 79th Street, \\ New York, NY, USA \\ ${ }^{2}$ Subcoordinación de Especies Prioritarias, Comisión Nacional Para el Conocimiento y Uso de la \\ Biodiversidad, Liga Periférico Insurgentes Sur 4903, Parques del Pedregal, 14010 Tlalpan, Mexico \\ ${ }^{3}$ Department of Biology (Zoology Section, Biogeography Research Lab.), Faculty of Science, Hacettepe \\ University, Beytepe, 06800 Ankara, Turkey
}

Received 13 March 2019; revised 9 April 2019; accepted for publication 10 April 2019

\begin{abstract}
In this study, we address the evolutionary relationships and discuss the biogeographical history of a complex and diverse group of ovenbirds, the Thripophagini. We reconstruct the phylogeny and estimate the time of divergence of this group, using sequences from two complete mitochondrial genes (cytochrome $b$ and NADH subunit 2) from a total of 115 fresh tissue samples. The results provide a better understanding of the phylogenetic relationships of the taxa within this group, some of which require a thorough taxonomic revision. We discuss the biogeographical history of the group, and find parallels with other previously studied Andean birds which may indicate that tectonic and climatic events might, at least in part, be linked to its diversification through the uplift of the Andes, the creation of new montane habitats and barriers, the evolution of Amazonian drainages and landscapes, and the climatic oscillations of the Pleistocene.
\end{abstract}

ADDITIONAL KEYWORDS: Andean biogeography - Andean diversification - Andean uplift - ovenbirds - Thripophagini.

\section{INTRODUCTION}

Moyle et al. (2009) introduced the name Furnariides to designate the infraorder of suboscine birds that was previously known as Furnariida (Irestedt et al., 2002; Ericson et al., 2003; Ericson \& Johansson, 2003). This group includes $\sim 651$ species of Neotropical birds primarily distributed in South America throughout a broad range of habitats (Remsen et al., 2018), and numerous studies have confirmed their monophyly (Irestedt et al., 2001, 2002; Chesser, 2004; Hackett et al., 2008; Claramunt, 2010). Within the infraorder, the Furnariidae - or ovenbirds - comprise almost 300 recognized species (Sibley \& Ahlquist, 1990; Moyle et al., 2009; Remsen et al., 2018), and has been described as being one of the most diverse avian groups (Claramunt, 2010).

Within the Furnariidae, the Synallaxinae include two tribes, Thripophagini and Synallaxini (Moyle et al.,

*Corresponding author. E-mail: esther.quintero@gmail.com
2009). The tribe Thripophagini includes the genera Acrobatornis, Metopothrix, Xenerpestes, Limnoctites, Cranioleuca, Siptornis, Thripophaga and Roraima (Moyle et al., 2009). Of these, Siptornis is distributed throughout the Andean highlands, whereas the species within Thripophaga, Xenerpestes and Cranioleuca are distributed both in the Andean highlands and in portions of the Neotropical lowlands (i.e. the Amazon Basin, the Atlantic Forest, the Pantepui, the Chocó, the Caatinga, the Pampas, and the Chaco); Cranioleuca is also found in the Central American highlands. Finally, the species of Acrobatornis, Limnoctites, Roraima and Metopothrix occur in isolated areas of the South American lowlands (Fig. 1). The tribe Thripophagini comprises a heterogeneous array of taxa, in terms of both morphology and ecology (Remsen, 2003; Claramunt, 2010). The diversity of nest morphology within the ovenbird family is so high that Irestedt et al. (2009) have suggested that it might be one of the factors that contributed to their high diversification rates, and 

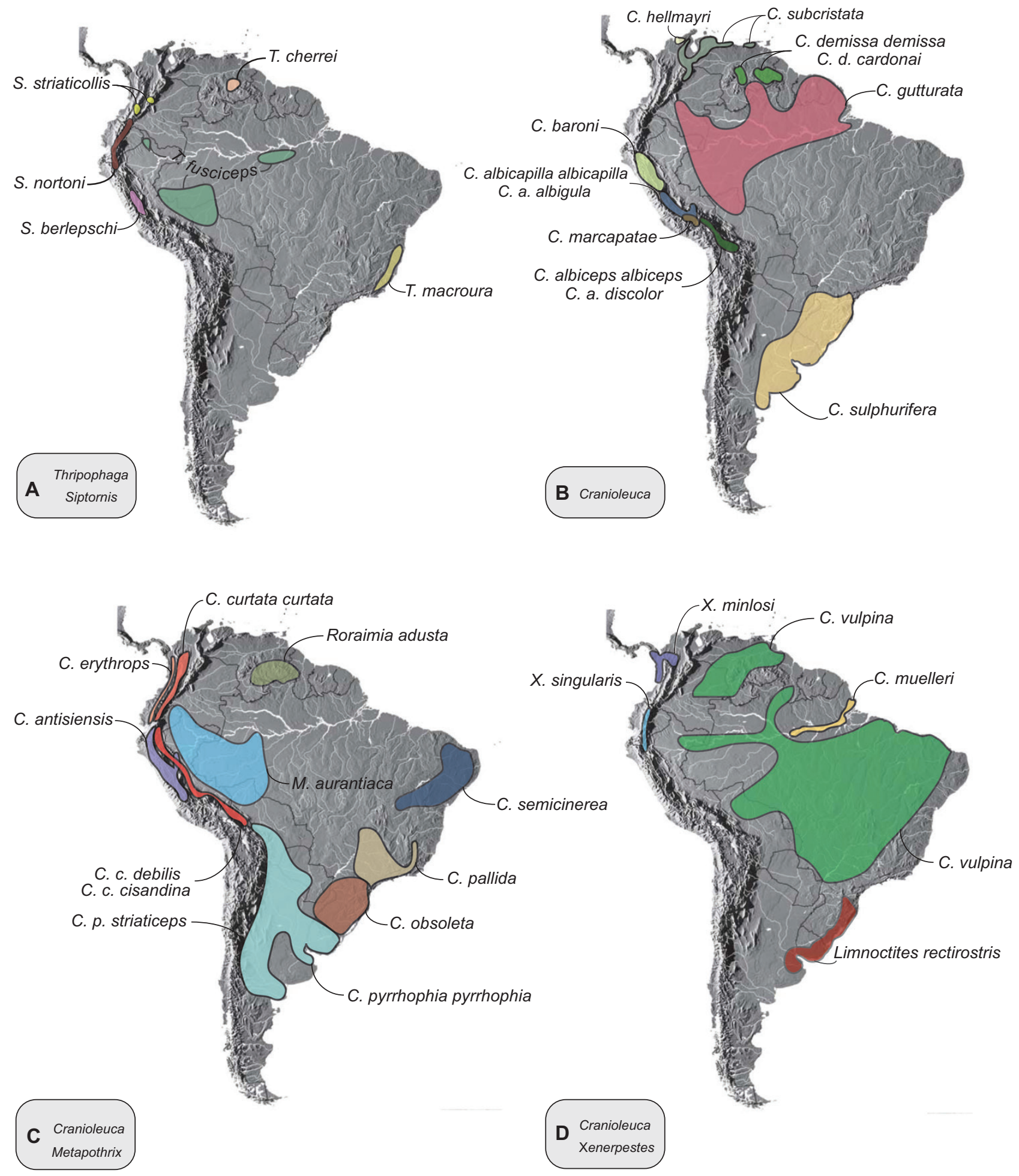

Figure 1. Distribution of the taxa within Thripophagini: A, Siptornis and Thripophaga; B, part of the genus Cranioleuca [C. gutturata, which needs to be renamed, as well as Limnoctites sulphurifera are included here (see text)]; C, part of the genus Cranioleuca and Metopothrix; D, part of Cranioleuca and Xenerpestes. Distributions were taken from del Hoyo et al. (2019). 
they posit this feature might have allowed the group to colonize and diversify into new environments.

The high morphological diversity of this group has resulted in extensive taxonomic flux in the arrangement of its taxa, and there remain doubts regarding the taxonomic status of some taxa. Here, we follow the taxonomy in del Hoyo \& Collar (2016). There is a need to clarify the boundaries of the genus Thripophaga, as Vaurie (1980) and Irestedt et al., (2009) have suggested that it does not form a monophyletic group. Within Cranioleuca, C. vulpecula was considered to be a subspecies of $C$. vulpina (Cory \& Hellmayr, 1925; Peters, 1951, Meyer De Schauensee, 1970; Ridgely \& Tudor, 1994), although Zimmer (1997) considered that they were separate species based on morphological, vocal and ecological characters. Belton (1985) placed C. obsoleta as a subspecies of C. pyrrhophia based on 'intermediate specimens', although Claramunt (2002) argued that there was no strong support for interbreeding between these two species. On the other hand, C. pyrrhophia has three described subspecies: C. p. pyrrhophia, C. p. striaticeps and C. p. rufipennis (Cory \& Hellmayr, 1925; Peters, 1951). Each of them is diagnosably distinct with regard to plumage, and they have disjunct distributions (Fig. 1C). Sibley \& Ahlquist (1990) and Maijer \& Fjeldsa (1997) proposed that C. henricae, C. pyrrhophia and C. obsoleta form a 'superspecies', a claim that was supported by the results of García-Moreno et al. (1999). According to S. Claramunt (pers. comm.) there is reason to believe that $C$. henricae might be a hybrid between C. p. rufipennis and C. curtata debilis, as $C$. henricae has some intermediate morphological features between these taxa. These two species are currently allopatric, with $C$. p. rufipennis found in the arid woodlands of La Paz and north-west Cochabamba, and C. c. debilis in the humid montane forests of Bolivia (the Yungas) south to Santa Cruz, but geographical overlap between these species may occur in as yet unsurveyed localities. Cranioleuca demissa has two described subspecies (Fig. 1B), C. d. demissa from the tepuis of the Duida subcentre of endemism (Cracraft, 1985), and C. d. cardonai (Phelps \& Dickerman, 1980) from the tepuis of the Gran Sabana subcentre of endemism (Cracraft, 1985). Cranioleuca erythrops has three subspecies, C. e. erythrops, C. e. rufigenis and C. e. griseigularis (Cory \& Hellmayr, 1925; Peters, 1951), all of which are diagnosably distinct based on plumage, and possess disjunct distributions. Cranioleuca curtata cisandina, C. c. curtata and C.c. debilis (Fig. 1C) are subspecies of C. curtata (Peters, 1951), although Cory \& Hellmayr (1925) recognized C. c. cisandina as a separate species. Cranioleuca antisiensis is described as having two subspecies, C. a. antisiensis and C. a. palamblae (Cory \& Hellmayr, 1925), each of them diagnosably distinct with regard to plumage, and with allopatric distributions (Fig. 1C). Cranioleuca baroni has three described subspecies, C. b. baroni, C. b. capitalis (Cory \& Hellmayr, 1925; Peters, 1951) and C. b. zaratensis, which was described by Koepcke (1961a). Although each of these taxa is diagnosably distinct based on plumage, Fjeldsa \& Krabbe (1990) proposed that C. pyrrhophia may form a superspecies with $C$. antisiensis and $C$. baroni, and that $C$. curtata should be treated as conspecific with C. erythrops. Cranioleuca baroni and C. antisiensis have been previously reported as being conspecific by Koepcke (1961b) and Fjeldsa \& Krabbe (1990), but Cory \& Hellmayr (1925) and Peters (1951) considered them as separate species. Although Remsen (2003: 187) noted that these two species had 'clearly distinct populations at the extreme of their ranges', $C$. baroni and $C$. antisiensis are allopatric, with $C$. baroni distributed in northern and central Peru in semiarid woodlands, whereas $C$. antisiensis is found from southern Ecuador to northern Peru in montane or subandean humid forests, so this argument alone is no reason for considering them as conspecific.

Irestedt et al. (2009) suggested that the radiation of Synallaxinae ovenbirds took place during the last 15 Mya, a time frame that was later corroborated by Derryberry et al. (2011), when the uplift of the Andes, and later the glaciations of the Pleistocene, were reshaping the landscape in South America, including the river systems and precipitation patterns (Hooghiemstra et al., 2000; Hoorn et al., 2010). Numerous authors have suggested that these tectonic and climatic changes had a strong influence on the diversification of Andean groups (Bates \& Zink, 1994; Bleiweiss, 1998; Pérez-Emán, 2005; Cadena et al., 2007; Chaves et al., 2007; Lutz et al., 2013; Quintero et al., 2013; Ceccarelli et al., 2016). The tribe Thripophagini, due to its diversity and distribution, can be used to test the idea that certain events within Earth's history, such as the orogenesis of the Andes and the glacial-interglacial periods of the Pleistocene, played an important role in its biotic assemblage. Thus, in this study we reconstruct the phylogeny and estimate the time of divergence of the Thripophagini, using sequences from two mitochondrial genes, and use this phylogenetic hypothesis to infer some of the biogeographical history of the group.

\section{MATERIAL AND METHODS}

\section{HABITAT CHARACTERIZATION AND ANCESTRAL CHARACTER-STATE RECONSTRUCTION}

To correlate current habitat distribution with the biogeographical history within Thripophagini, we characterized the ecological habitat in which each species breeds based on Fjeldsa \& Krabbe (1990), 
Remsen (2003) and Hooghiemstra et al. (2006). We divided forested vegetation into tropical lowland or wet forest (sea level to 1000-1200 m), subandean or lower montane forest (800-2300 m), Andean or upper montane forest (2300-3300 m) and subpáramo belt (3200-3600 m). Open vegetation in the Andes is dominated by the páramo (3500 to $\sim 4200 \mathrm{~m}$ ), above the tree line, containing bunch-forming grasses, with a diverse assemblage of herbaceous plants and small shrubs scattered among them (Neill, 1999), whereas open vegetation in the lowlands is divided into swamps, woodlands, Chaco and Pampas (Table 1). Each individual was classified into the following areas of endemism based on Cracraft (1985): Gran Sabana, Duida, northern Ecuador, southern Ecuador, northern Peru, central Peru, southern Peru, Austral Andes, Napo, Inambari, Para, Rondonia, Chaco, Caatinga, Patagonia, Pampean, eastern Panama, Coiba Island and Central American highlands (Table 1).

\section{SAMPLING, DNA EXTRACTION AND AMPLIFICATION}

Thorough sampling is essential for understanding the temporal and spatial patterns of diversification within any group. As many of the described species within the tribe Thripophagini have two or more recognized subspecies, we included as many of them as possible in order to test hypotheses of phylogenetic species limits with independent DNA data. For taxonomy, we consulted Peters (1951), Meyer De Schauensee (1970), Fjeldsa \& Krabbe (1990), Ridgely \& Tudor (1994), Remsen (2003) and Remsen et al. (2018). The species names in this paper follow del Hoyo \& Collar (2016), and we adhere to the phylogenetic species concept coined by Cracraft (1997).

A total of 115 fresh tissue samples were included in the molecular analysis (Table 1), and sequences for some outgroups were obtained from GenBank (Table 1). Extractions were performed using the DNeasy kit (Qiagen), and the complete cytochrome b (cyt b) and NADH subunit (ND2) mitochondrial DNA (mtDNA) genes were amplified using general primers (Sorenson et al., 1999). Amplifications were performed using GoTaq Polymerase (Promega). Amplification products were visualized by electrophoresis, and purified using Multiscreen PCR plates (Millipore). Purified PCR products were sequenced with the same primers used during amplifications, and run on a 3730 Automated DNA Sequencer (Perkin-Elmer, ABI) following standard protocols (Applied Biosystems, 2009).

\section{PHYLOGENETIC ANALYSES}

Sequences were edited and examined for the presence of stop or nonsense codons using Sequencher 4.5 (GeneCodes Corporation). The incongruence length difference (ILD) test (Farris et al., 1995) was performed in PAUP v.4.0b10 (Swofford, 2002) to assess the level of incongruence of phylogenetic signal between the two mitochondrial genes. Three independent analyses were performed. Maximum-parsimony (MP) was implemented in PAUP v.4.0b10 (Swofford, 2002), using PAUPRat (Nixon, 1999) with $10 \%$ of the characters perturbed, 200 iterations and ten independent parsimony replicates. Branch support was estimated through non-parametric bootstrapping (Felsenstein, 1985) in PAUP v.4.0b10 (Swofford, 2002), via a heuristic search, TBR branch swapping, and 1000 replicates with ten random stepwise addition sequence replicates. Maximum-likelihood (ML) was performed using GARLI (Zwickl, 2006), with GTR+G+I as the nucleotide substitution model, estimating base frequencies and the proportion of invariant sites. Two parallel analyses were run, which were automatically terminated when no significant improvements in topology were found after 2 million generations. Bayesian inference (BI) was implemented in MrBayes v.3.1.1 (Huelsenbeck \& Ronquist, 2001) using a partitioned model approach to account for potential differences in evolutionary model parameters between the two genes. The best model for each gene partition was selected using MrModeltest 2.3 (Nylander, 2004). Two independent analyses were run using four simultaneous Markov chains for 10 million generations, with trees being sampled every 1000 generations, keeping 9000 trees from each analysis. The resulting 18000 sampled trees were used to compute posterior probabilities for each node. During all searches, Asthenes steinbachi, Asthenes pyrrholeuca, Schizoeaca helleri, Synallaxis ruficapilla, Synallaxis azarae and Hellmayrea gularis were used as outgroups (Moyle et al., 2009). All analyses were run on the CIPRES portal v.3.1 (Miller et al., 2010).

\section{DIVERGENCE TIME ESTIMATES}

Irestedt et al. (2009) calculated the divergence dates within the Furnariides, and according to their results, the ovenbird-woodcreeper radiation started to diverge at $\sim 33 \mathrm{Mya}$, while the Synallaxines started to diverge at $\sim 19$ Mya. We used their results to estimate divergence times within the Thripophagini using BEAST (Drummond \& Rambaut, 2007). To account for the uncertainty of using results from a previous analysis, which carry a level of uncertainty themselves, three independent analyses were run using priors based on the mean as well as the upperand lower-bound confidence intervals reported by Irestedt et al. (2009), to provide a very conservative bracket for the estimated dates. Thus, the priors for the node between Phacellodomus and the remainder of the Synallaxines were set at 15, 17.45 and 22.5 Mya (node A, Table 2), those between Hellmayrea gularis 


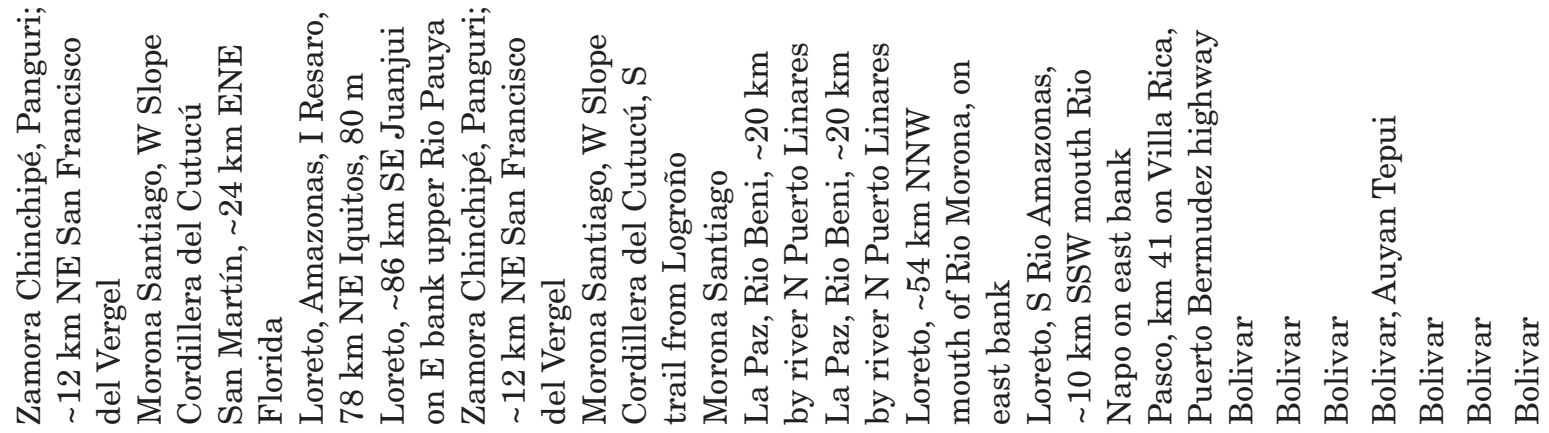

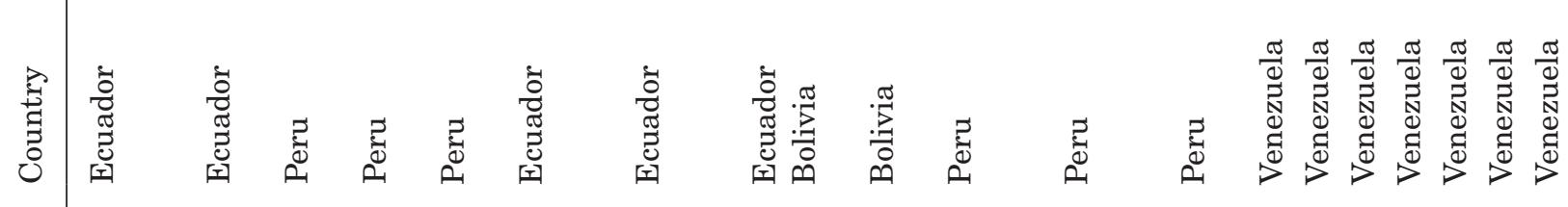

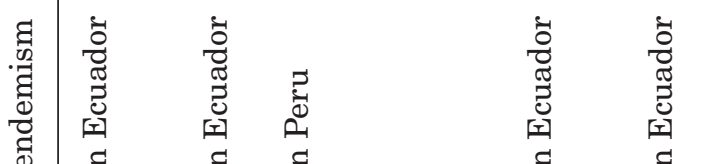

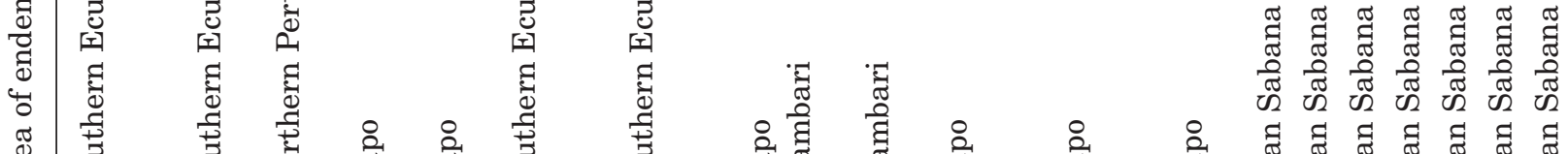

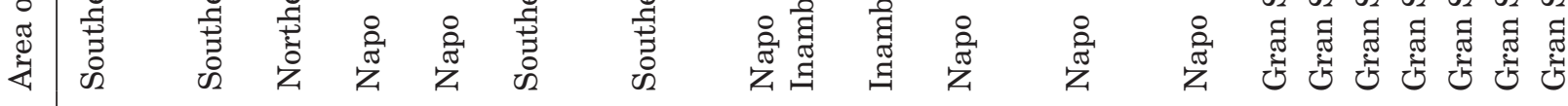

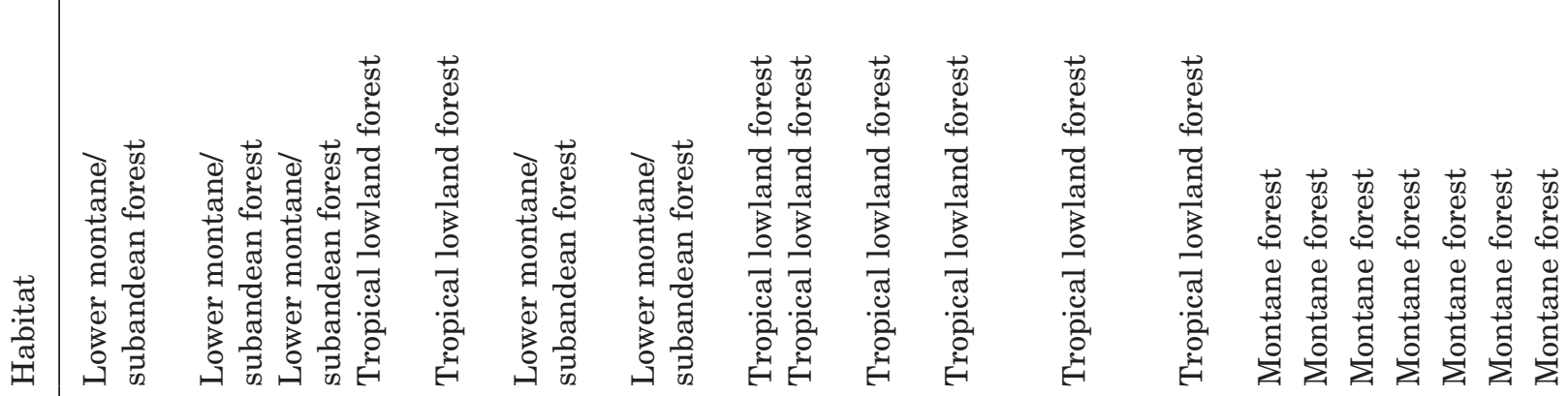

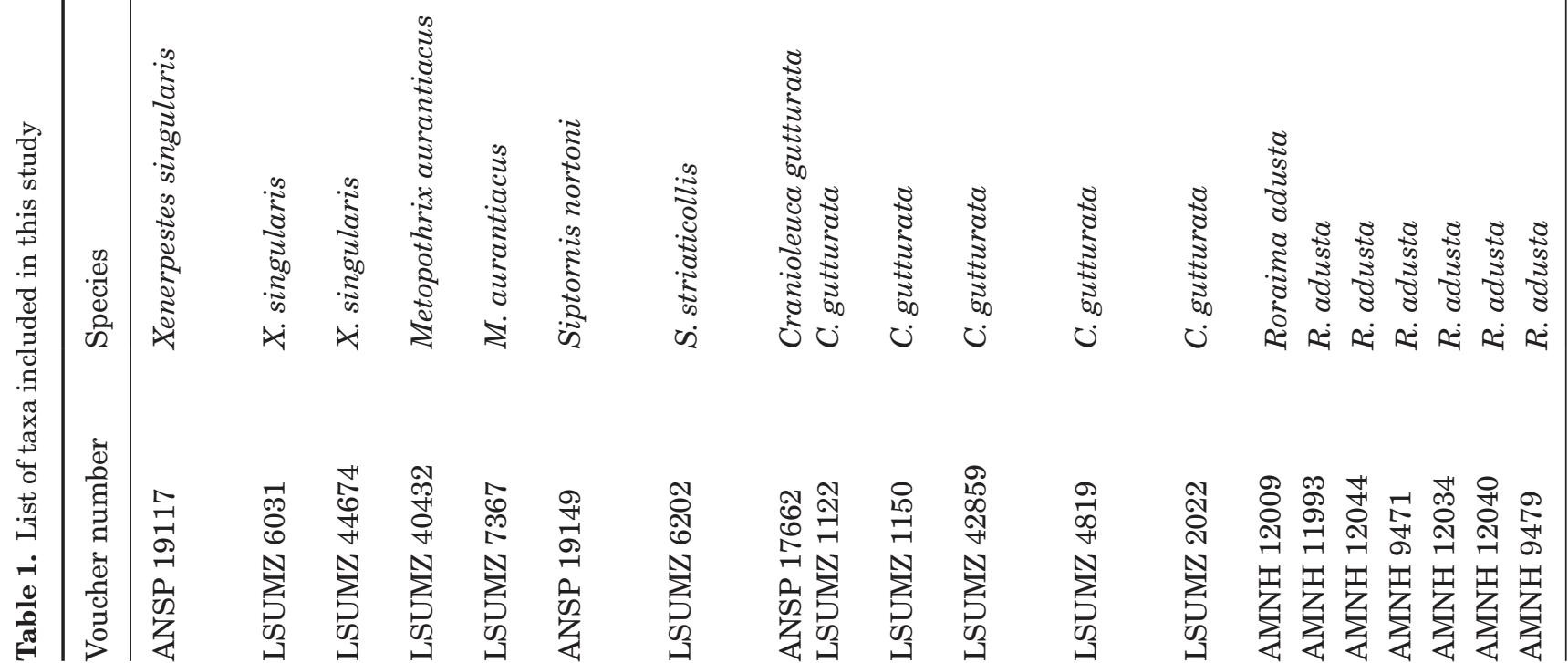




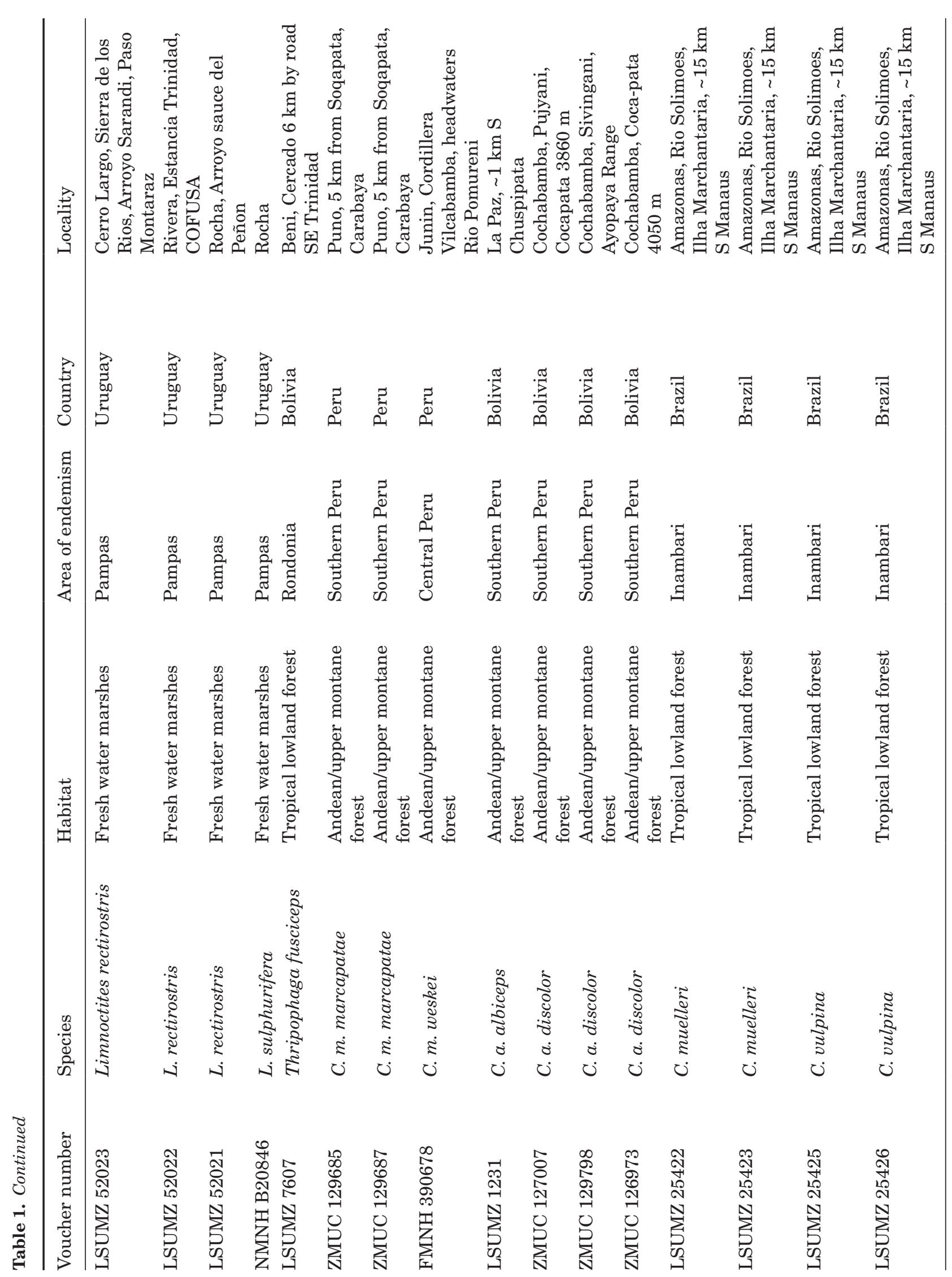




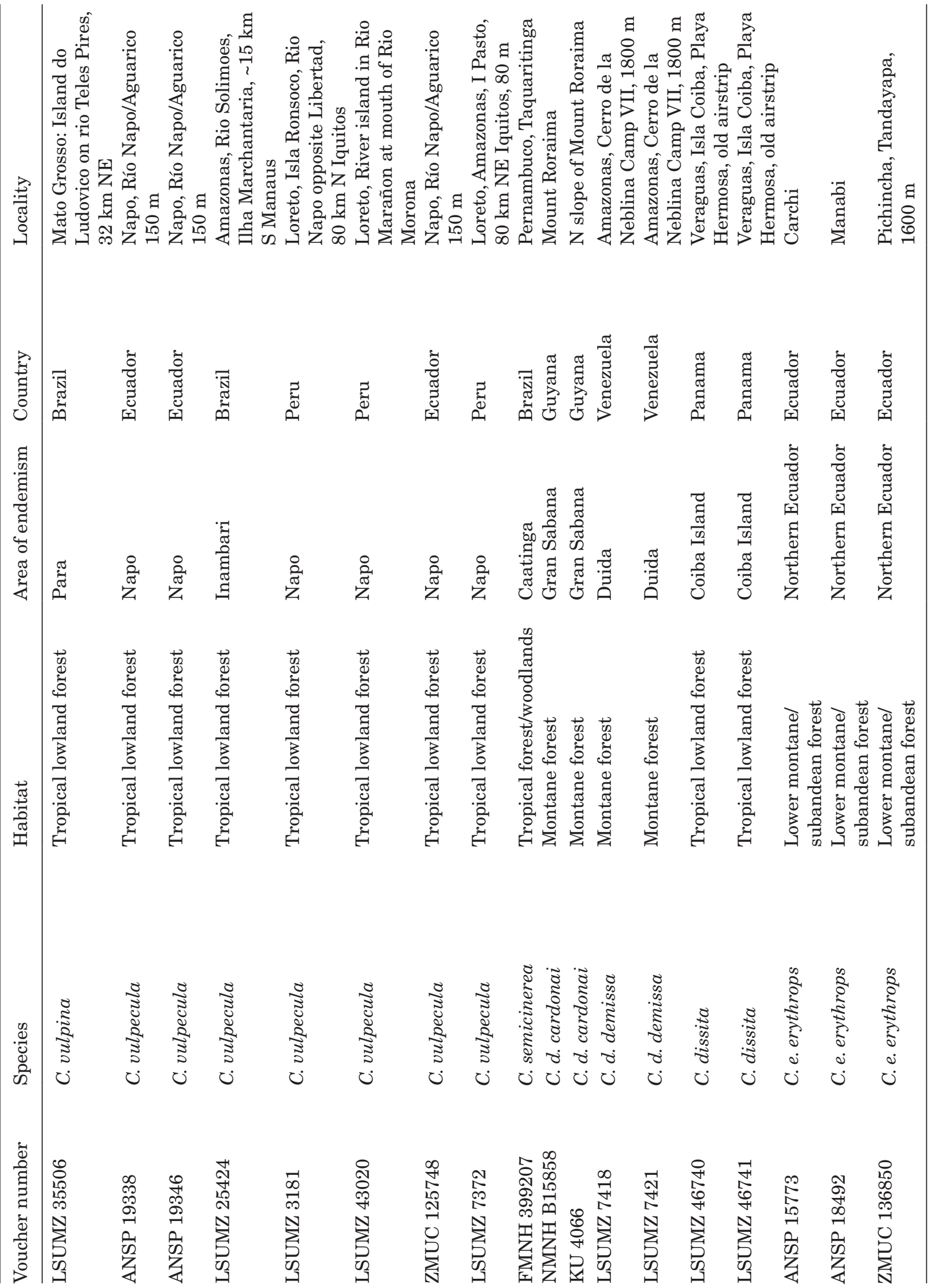




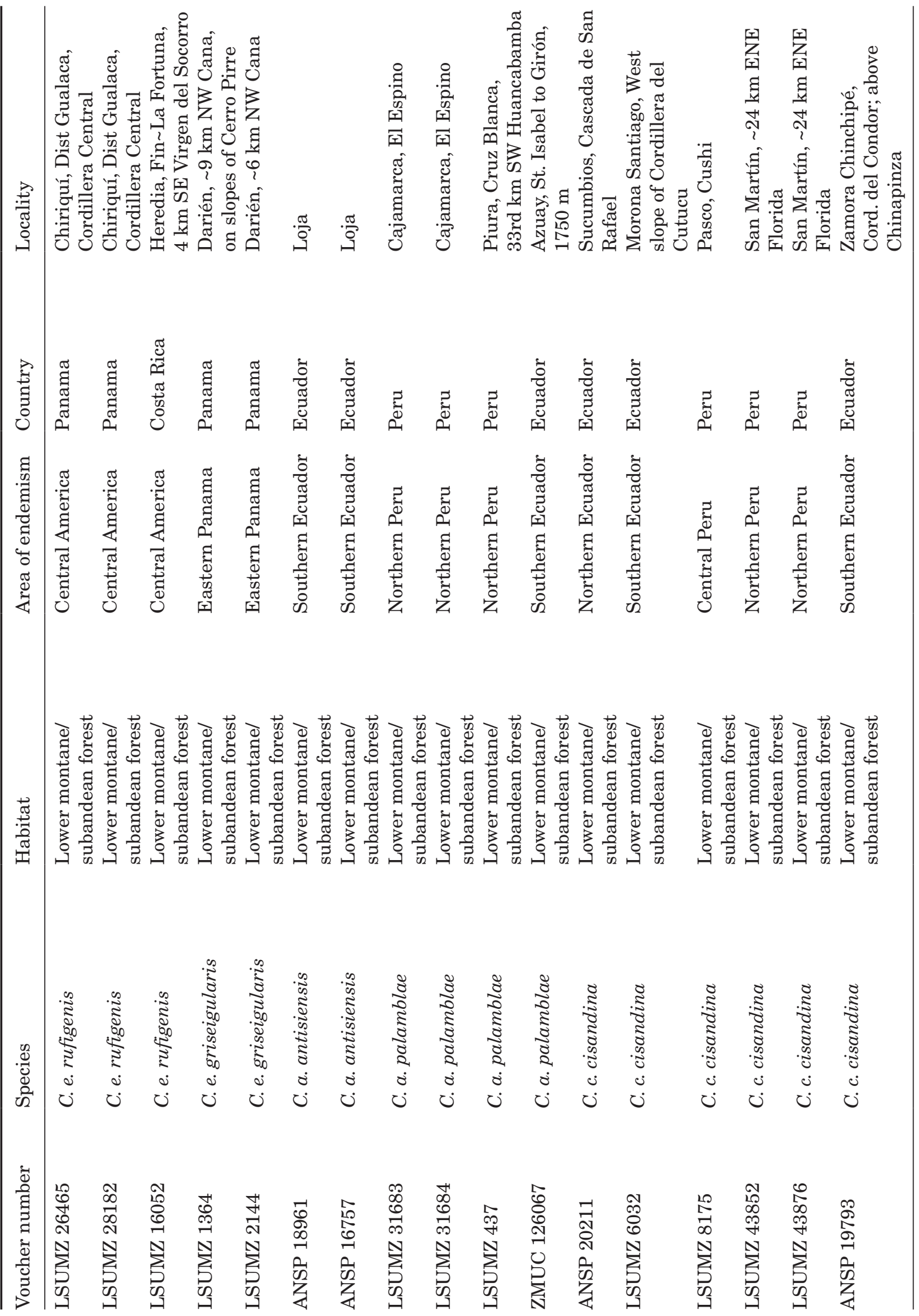




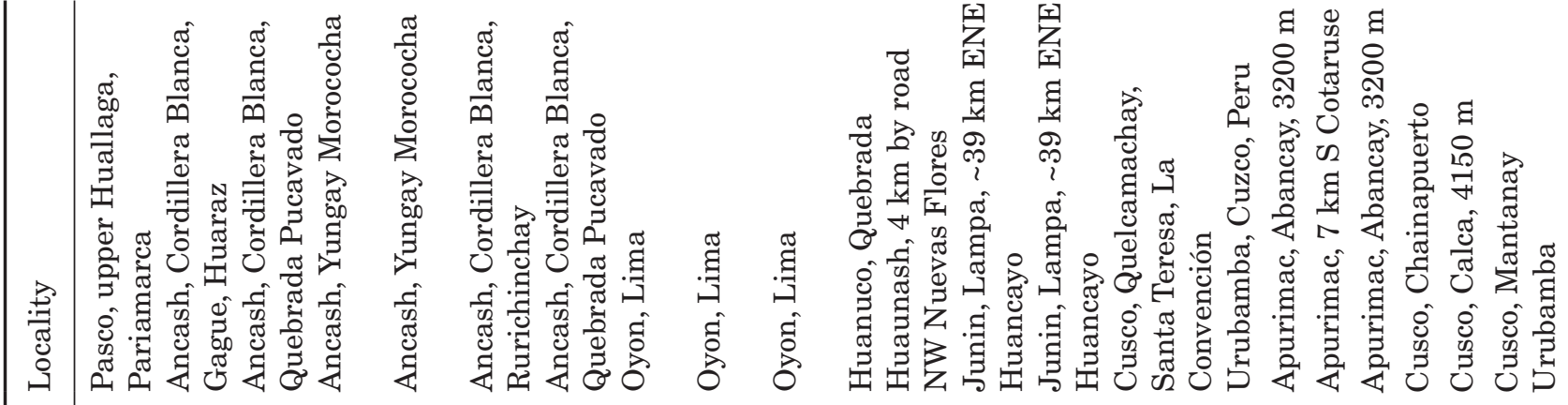

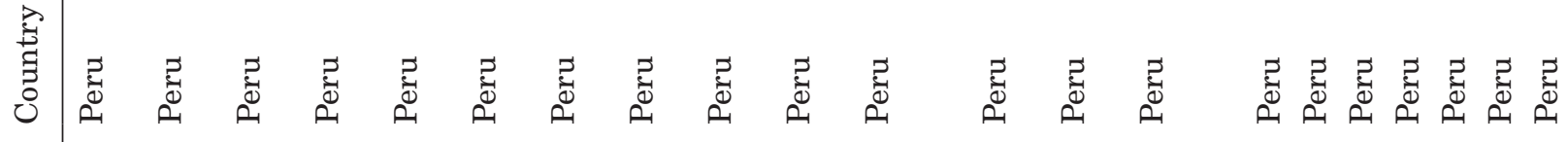

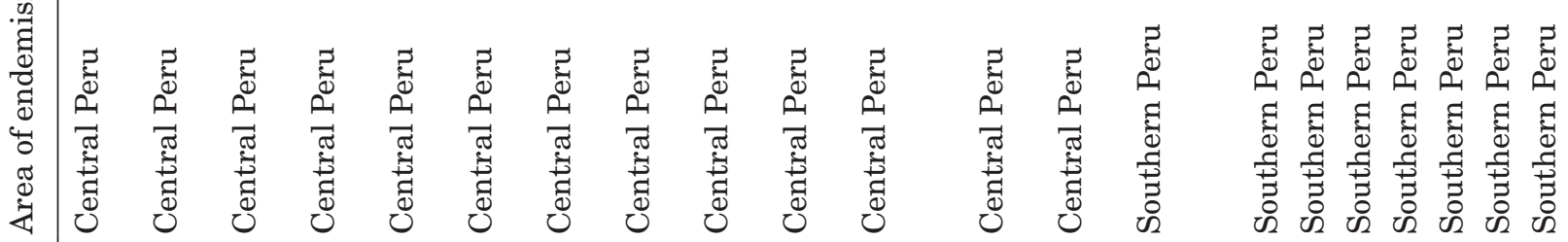

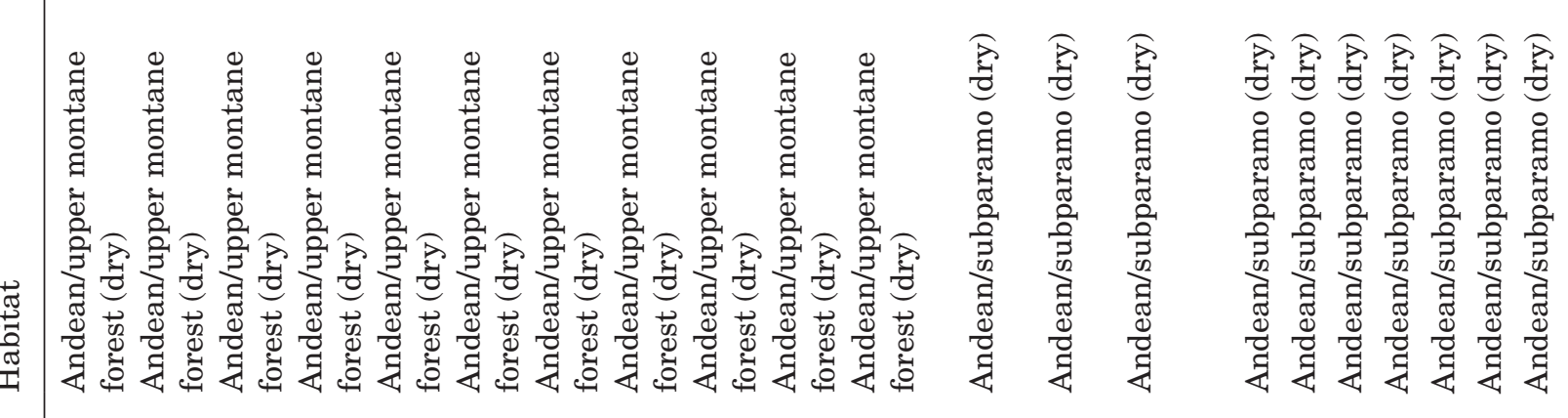

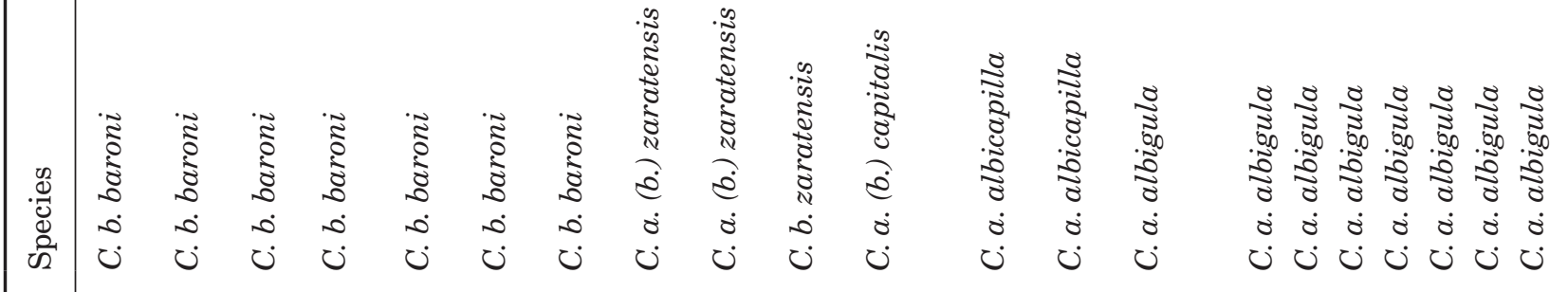




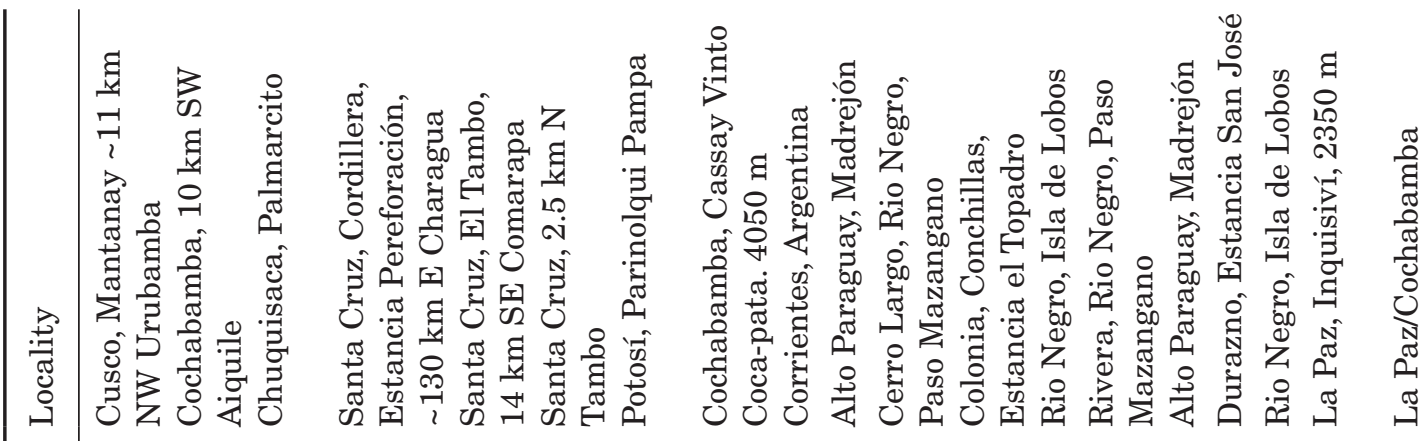

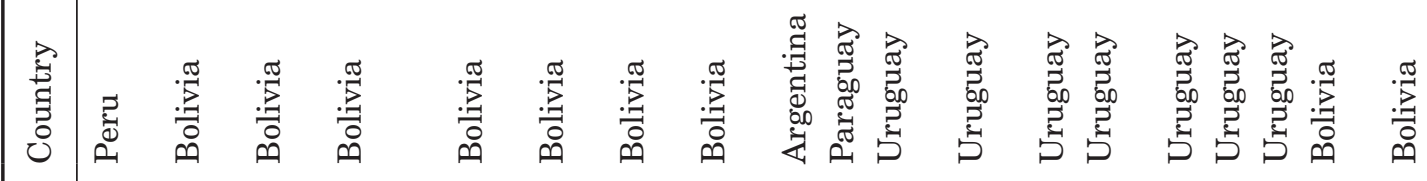

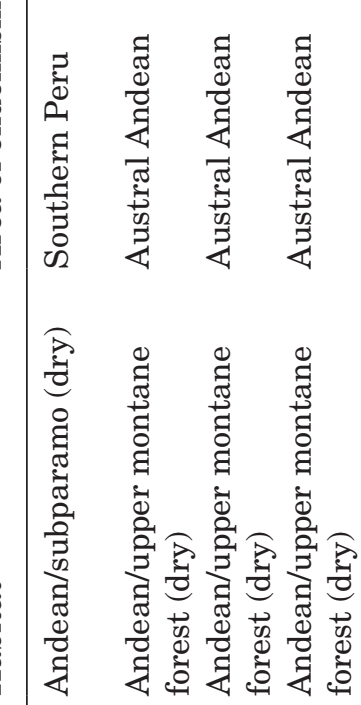

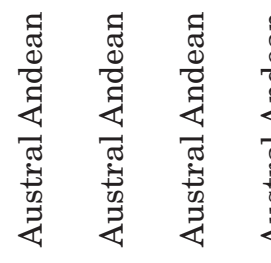

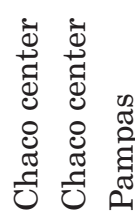
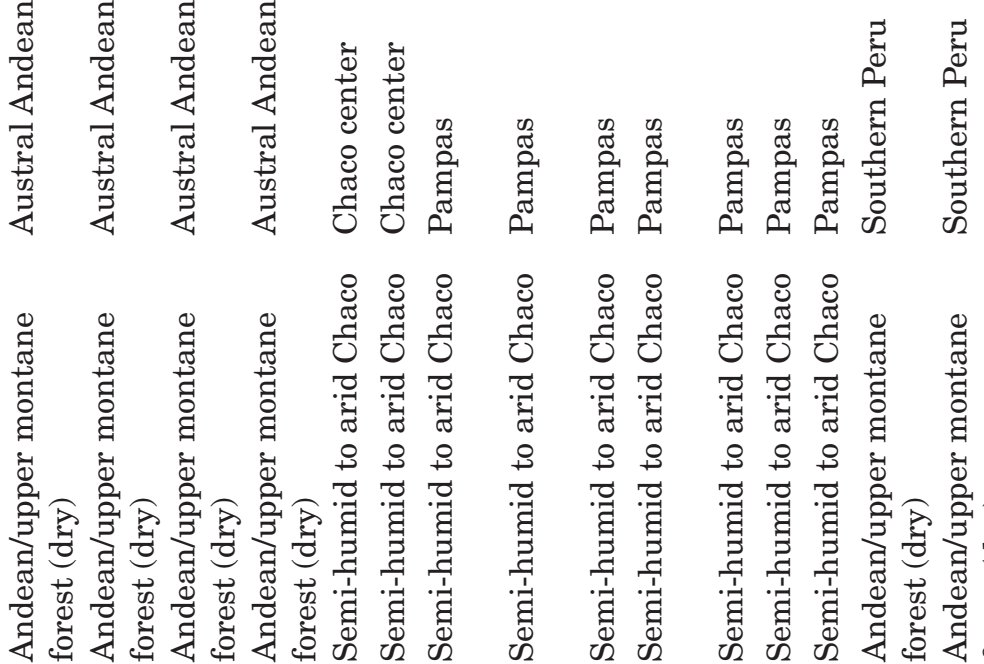

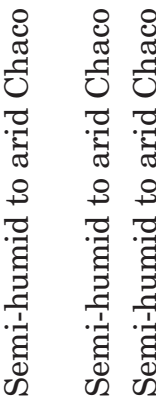
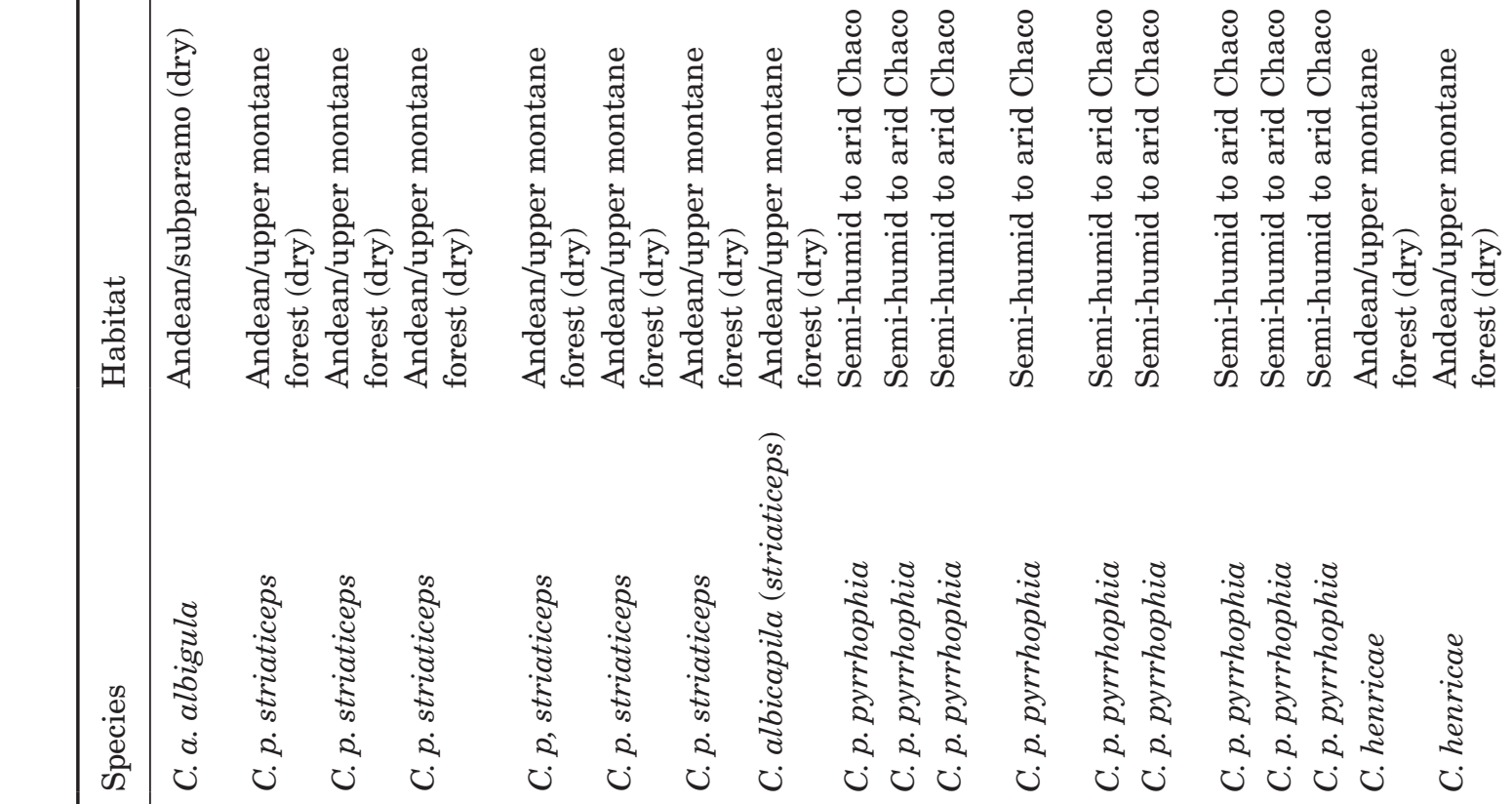


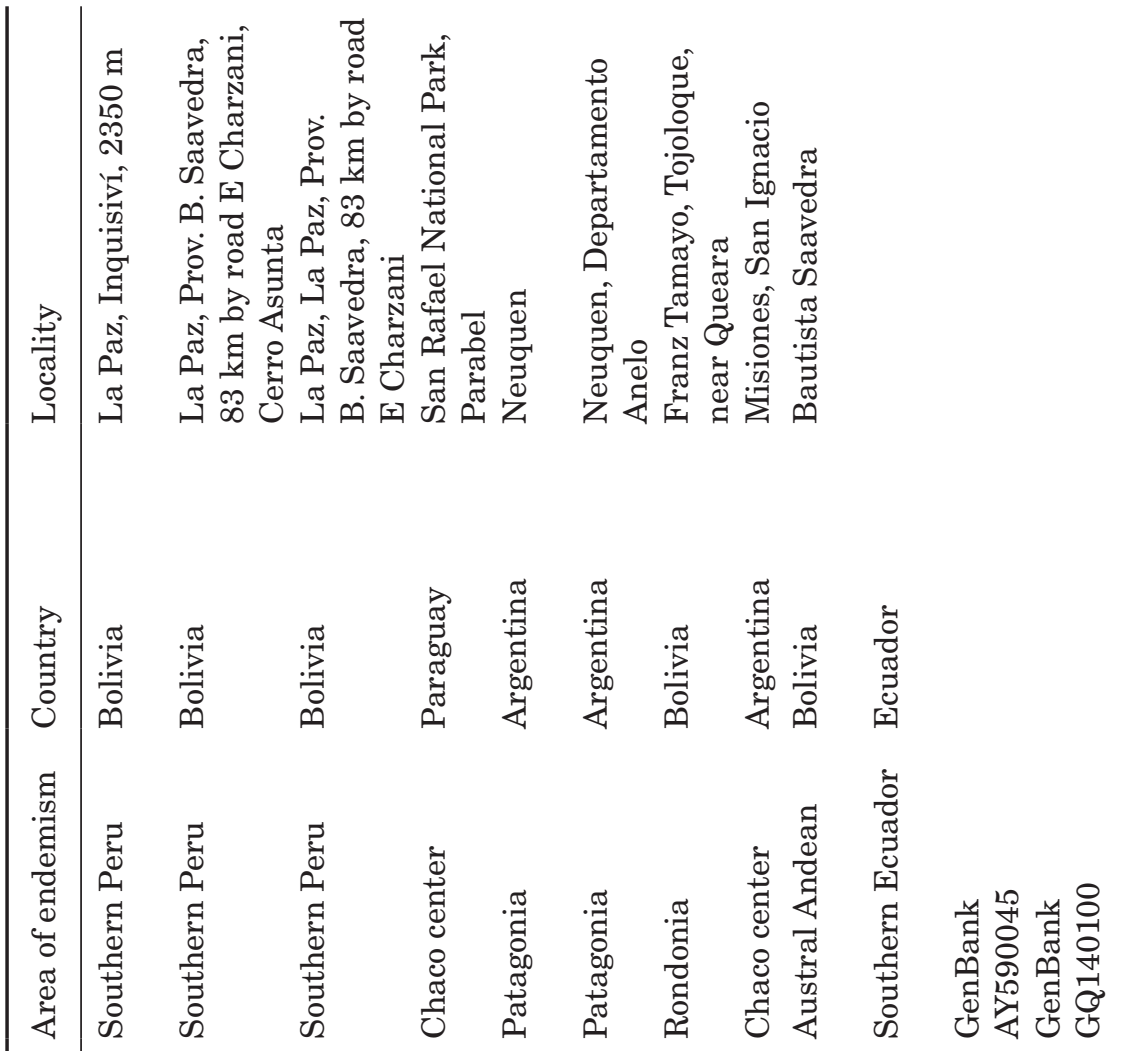

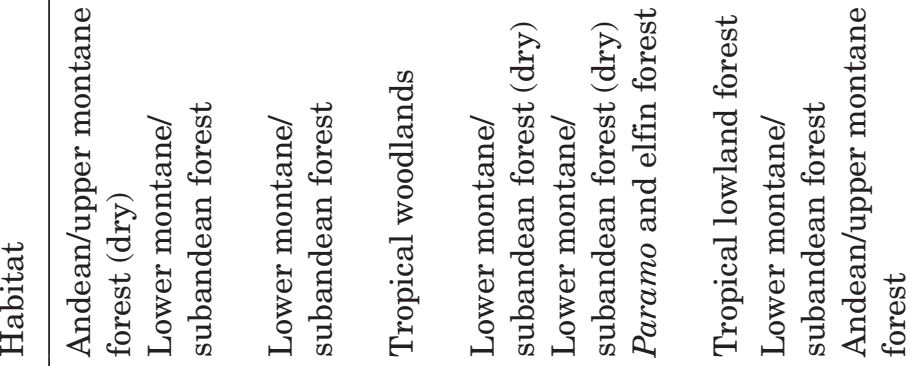

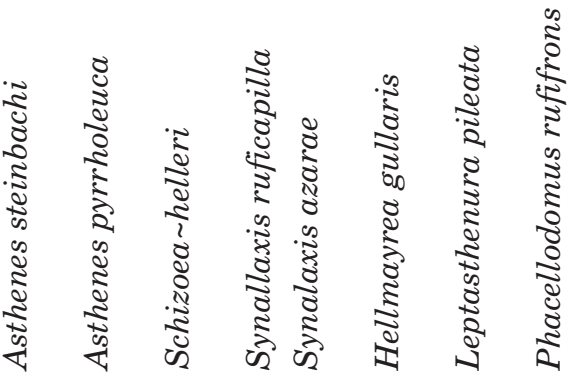

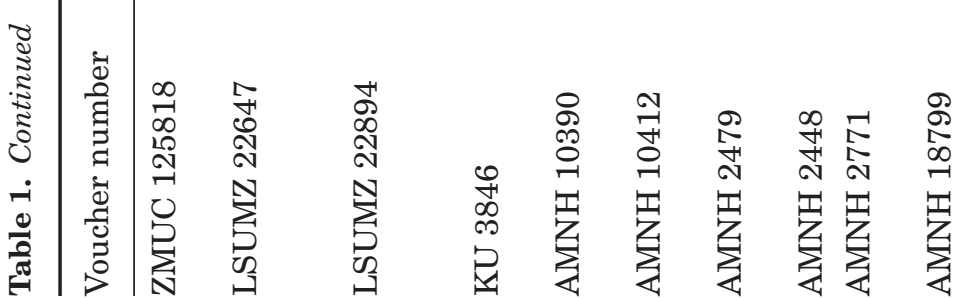

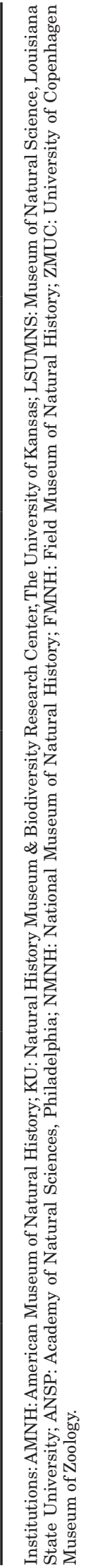


Table 2. Dates of diversification (Mya) for the tribe Thripophagini and their confidence intervals estimated by BEAST; nodes correspond to those of Figure 3

\begin{tabular}{llccc}
\hline Node & Lower bound & Mean & $95 \%$ CI & Upper bound§ \\
\hline Node A & 15 & 17.45 & & 22.5 \\
Node B & 13.7 & 16.38 & & 21.5 \\
Node C & 13.4 & 15.63 & $11.4-15.1$ & 20.3 \\
1 & 11.8 & 13.3 & $9.3-13.1$ & 17.5 \\
2 & 9.3 & 11.2 & $6.7-11.4$ & 14.7 \\
3 & 7.4 & 8.9 & $6.7-10.1$ & 11.0 \\
4 & 7.0 & 8.4 & $4.5-7$ & 7.6 \\
5 & 4.8 & 5.8 & $4.3-6.6$ & 7.1 \\
6 & 4.5 & 5.4 & $1.8-3.7$ & 3.6 \\
7 & 2.3 & 2.7 & $4.1-6.3$ & 6.7 \\
8 & 4.3 & 5.1 & $3.4-5.3$ & 5.7 \\
9 & 3.6 & 4.4 & $0.8-2.1$ & 1.9 \\
10 & 1.2 & 1.5 & $2.7-4.2$ & 4.4 \\
11 & 2.8 & 3.4 & $1.9-3.7$ & 3.7 \\
12 & 2.3 & 2.8 & $1.4-3$ & 2.9 \\
13 & 1.8 & 2.2 & $2.2-3.5$ & 3.7 \\
14 & 2.3 & 2.8 & $1.5-2.7$ & 2.7 \\
15 & 1.7 & 2.1 & $0.2-0.7$ & 0.5 \\
16 & 0.3 & 0.4 & $0.7-1.6$ & 1.5 \\
17 & 0.9 & 1.1 & $0.07-0.5$ & 0.3 \\
18 & 0.2 & 0.3 & $1.6-2.7$ & 2.8 \\
19 & 1.7 & 2.2 & $1.3-2.4$ & 2.4 \\
20 & 1.5 & 1.9 & $0.3-1.1$ & 1 \\
21 & 0.6 & 0.7 & $1.5-2.5$ & 0.9 \\
22 & 1.6 & 2 & $1.3-2.3$ & 2.3 \\
23 & 1.4 & 1.8 & $0.6-1.6$ & 0.9 \\
24 & 0.9 & 1.1 & $0.4-1$ & \\
25 & 0.6 & 0.7 & & \\
\hline
\end{tabular}

*Mean divergence dates obtained using the lower-bound confidence interval reported by Irestedt et al. (2009) as a prior. $\dagger$ Mean divergence dates obtained using the mean reported by Irestedt et al. (2009) as a prior.

$\$ 95 \%$ confidence interval for the divergence dates using the reported mean as a prior.

$\S$ Mean divergence dates obtained using the upper bound confidence interval reported by Irestedt et al. (2009) as a prior.

and the rest of the clade were $13.7,16.38$ and 21.5 Mya (node B, Table 2), and those for the node that splits Asthenes + Schizoeaca from the rest of the group were 13.4, 15.63 and 20.3 Mya (node C, Table 2). In all cases a normal distribution prior with a standard deviation of 1.0 Myr was used on the ages of the calibrated nodes, which allows for a bidirectional distribution of the uncertainty during the estimation (Ho \& Phillips, 2009). For this analysis, a reduced matrix of both $N D 2$ and cyt $b$ genes was used, containing only one or two individuals per basal taxonomic unit, plus Leptasthenura as the outgroup (Moyle et al., 2009). The model parameters for BEAST were computed using BEAUti, with the following settings: GTR + invariant sites as the nucleotide substitution model, a relaxed, uncorrelated lognormal clock model, and a Yule process as the tree prior. A chain length of 10 million was used, and after a burn-in of 1000 the resulting trees were summarized via TreeAnnotator v.1.5.1, using the maximum clade credibility option as target tree type, and mean heights for node heights, whereas the consensus was visualized and edited using FigTree v.1.31 (Rambaut, 2009).

\section{RESULTS}

\section{PHYLOGENETIC ANALYSES}

The sequences from both cyt $b$ (1092 bp) and ND2 (1041 bp) genes (available in GenBank) were aligned manually in Sequencher 4.5 (GeneCodes Corporation) and checked for the presence of stop codons (there were none). The results of the ILD test rejected incongruence between the genes $(P>0.05)$. The ten 


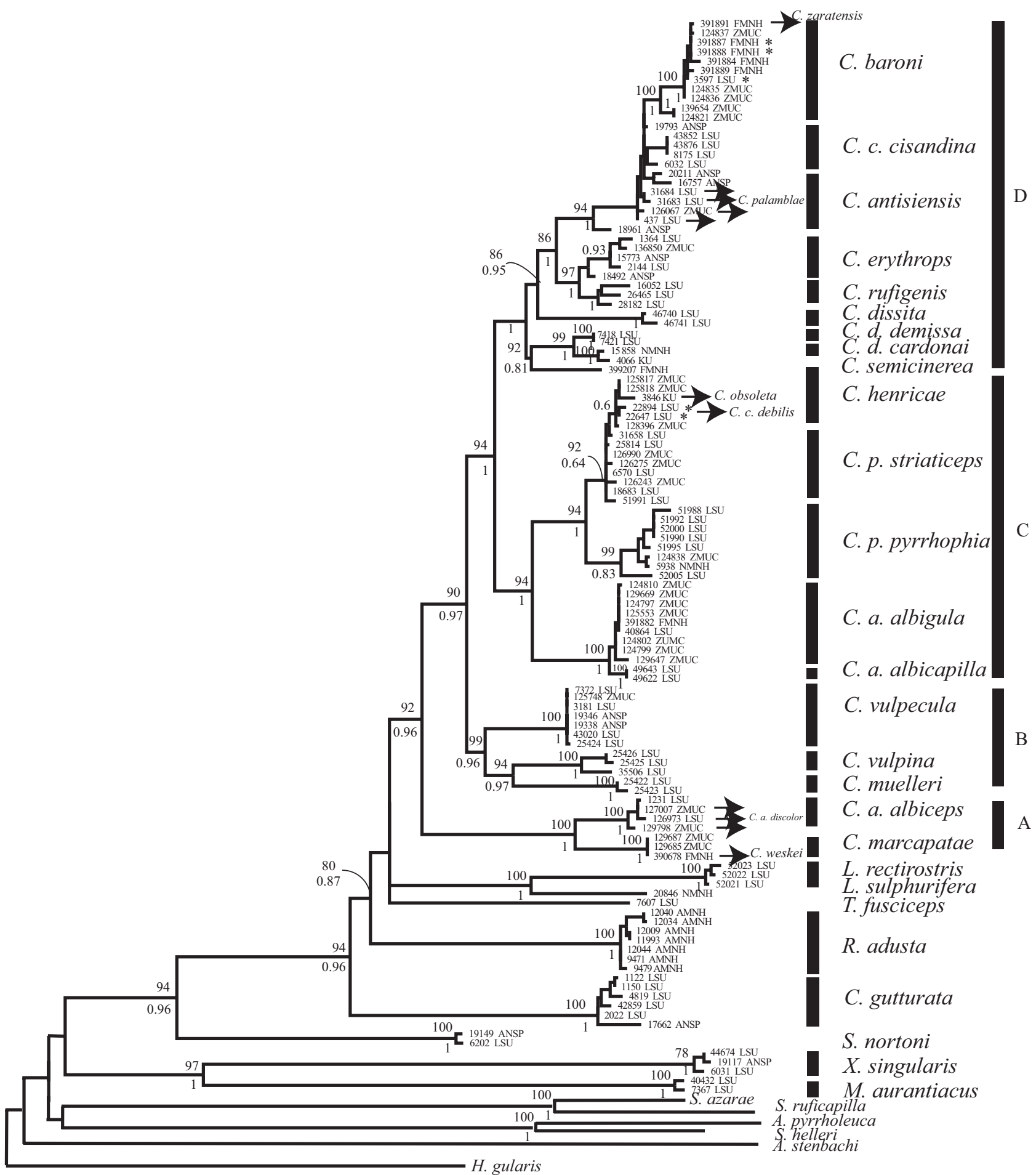

Figure 2. Maximum-likelihood phylogram of the tribe Thripophagini. Bootstrap support values are depicted above branches, while posterior probabilities are given below. Voucher numbers correspond to those in Table 1. Individuals of C. c. debilis nested within C. henricae are marked with an asterisk, as well as those of C. antisiensis nested within C. baroni (see text and Table 1). 
replicates of the MP searches yielded between 165 and $184 \mathrm{MP}$ trees of 1791 steps each, and the majority consensus of them (not shown). For the BI analysis, the GTR+I+G model of substitution was selected for cyt $b$, while the $\mathrm{HKY}+\mathrm{I}+\mathrm{G}$ model was selected for ND2 through MrModeltest v.2.3 using the Akaike's information criterion (AIC). The arithmetic mean of the Bayes factor for the two simultaneous BI analyses was $\operatorname{lnL}-11$ 898.28. The $\mathrm{ML}$ analysis had a final score of $\operatorname{lnL}=-11769.9675$, and Figure 2 presents the ML phylogram with bootstrap support values as well as posterior probabilities from the BI analysis.

Topologies from the three analyses largely agree, although in the ML analysis Thripophaga was sister to the clade of Cranioleuca + Limnoctites, in the BI analysis Limnoctites was sister to the clade of Cranioleuca + Thripophaga and in the MP analysis the clade of Limnoctites + Thripophaga was sister to Cranioleuca. Also, the placement of $C$. obsoleta differs among the three analyses: in the ML analysis it was nested within $C$. henricae, whereas in the MP and BI analyses it was not, and was sister to the clade of C. $p$. pyrrophia + C. $p$. striaticeps. Nevertheless, both in the case of the relationships among Cranioleuca, Limnoctites and Thripophaga, and in the placement of C. obsoleta, the conflicting nodes had low support in all three analyses.

Within the Thripophagini, Xenerpestes and the monotypic genus Metopothrix form a well-supported clade (Fig. 2). This clade is sister to the rest of the tribe, in which Siptornis is sister to a well-supported clade containing the polyphyletic Cranioleuca, as well as Roraima, Limnoctites and Thripophaga (Fig. 2). Within this clade, the taxon currently classified as Cranioleuca gutturata does not belong to the genus Cranioleuca, and thus a new genus will be erected to reflect its different taxonomic position (Fig. 2; taxonomic work in progress). This species is sister to the rest of the clade. Roraima, in turn, is sister to the clade that contains Limnoctites, Thripophaga and Cranioleuca (Fig. 2). As previously mentioned, there is no agreement across analyses with respect to the relationships among these three genera. The branch length of the node leading to this clade is very short, suggesting that the split among the three might have happened almost simultaneously. Within Limnoctites, L. rectirostris is sister to Cranioleuca sulphuriphera (Limnoctites sulphiriphera), and the latter should therefore be considered as part of Limnoctites instead of Cranioleuca.

Excluding C. gutturata and L. sulphuriphera, which are not closely related to the other species within Cranioleuca (Fig. 2), the remainder of the species in this genus form a well-supported monophyletic group. Cranioleuca can be partitioned into four clades, A-D (Fig. 2). Clade A contains C. marcapatae marcapatae,
C. m. weskei, C. albiceps discolor and C. a. albiceps. The two subspecies within C. albiceps (C. a. abiceps and $C$. a. discolor) were not recovered as different clades in the molecular phylogeny. The same was true for those within C. marcapatae: C. m. marcapatae and C. $m$. weskei (Remsen, 1984), which were recovered in the same clade (Fig. 2).

Clade $\mathrm{B}$ is unique in that it is the only one containing species found solely in Amazonia (Fig. 1D). The results from our molecular phylogeny suggest that $C$. vulpecula and C. vulpina are indeed different taxa, and show that they are not each other's sister species, as C. vulpina is sister to C. muelleri, and together they are sister to C. vulpecula (Fig. 2).

Clade C contains Cranioleuca albicapilla albicapilla, C. albicapilla albigula, C. pyrrhophia, C. striaticeps, C. henricae and C. obsoleta. Within it C. a. albicapilla and C.a.albigula are sister groups in the molecular phylogeny (Fig. 2). Clade $\mathrm{C}$ is sister to the one formed by the pyrrhophia species-group, which contains C. pyrrhophia pyrrhophia, C. p. striaticeps, C. p. rufipennis, C. henricae and $C$. obsoleta. In our analyses, the position of C. obsoleta varied, and was not supported in any of them. Thus, there is a need to include more samples of C. obsoleta, as having only one individual is probably the cause of this lack of resolution. Moreover, we found that C. p. pyrrhophia and C. p. striaticeps belong to separate clades (Fig. 2), although there is one individual of C. p. striaticeps nested within C. pyrrhophia. Moreover, within C. p. striaticeps, we found one bird labelled as C. a. albicapilla (ZMUC 126990) that, because of its distribution (Cochabamba; Table 1), is probably a mislabelled individual belonging to C. p. striaticeps, as C. a. albicapilla does not reach Bolivia (Fig. 1B; Remsen, 2003). Cranioleuca p. striaticeps and C. henricae are paraphyletic on the gene tree (Fig. 2), and within C. henricae, we found two individuals of C. curtata debilis (LSUMNS 22647, LSUMNS 22894). Cranioleuca henricae is diagnosably distinct in plumage from C. curtata debilis, C. p. rufipennis and C. p. striaticeps. Cranioleuca p. rufipennis was not sampled in the molecular phylogeny.

Clade D contains Cranioleuca semicinerea, C. demissa, C. d. cardonai, C. dissita, C. erythrops, C.rufigenis,C.griseigularis, C.antisiensis,C.palamblae, C. curtata, C. curtata debilis, C. cisandina, C. b. baroni, C. b. capitalis and C. b. zaratensis. The two subspecies within C. demissa, C. d. demissa, and C. d. cardonai, are sister groups in the molecular phylogeny, and together they are sister to C. semicinerea (Fig. 2). This clade is sister to another that contains $C$. dissita, from Coiba Island (Fig. 1D), which in turn is sister to the remainder of the group. Cranioleuca dissita was traditionally recognized as a subspecies of $C$. vulpina (Wetmore, 1957), but the results of this study show that it belongs a different clade, not related to the former 
(Fig. 2). The remainder of the group is divided into two clades. The first contains C. erythrops and C. erythrops rufigenis, and the other $C$. antisiensis, $C$. cisandina and C. baroni (Fig. 2). Cranioleuca e. griseigularis was not recovered as a separate species in the molecular phylogeny, as the two individuals included were nested within C. erythrops. The two described subspecies of $C$. antisiensis, $C$. antisiensis antisiensis and C. a. palamblae, are nested in the same clade. The same is true for the three subspecies described for C. baroni, i.e. C. baroni baroni, C. b. capitalis and C. b. zaratensis, which, although diagnosably distinct based on plumage, were not recovered as different clades in the molecular phylogeny (Fig. 2). We also found that C. baroni, C. antisiensis and C. cisandina are recovered as part of the same clade, while C. pyrrhophia is part of a different group (clade C). Although C. baroni, C. antisiensis and C. cisandina are paraphyletic with regard to mtDNA with respect to each other, each is diagnosably distinct in plumage. The results of the molecular phylogeny (Fig. 2) show that some individuals identified as $C$. antisiensis were nested within C. baroni (FMNH 391887, FMNH 391884, LSUMNS 3597). However, the distributions of these specimens in central Peru (Table 1) suggest that these might be individuals from $C$. b. capitalis (LSUMNS 3597) and C. b. zaratensis (FMNH 391887 , FMNH 391884), as C. antisiensis (Fig. 1c) only reaches northern Peru (Remsen, 2003).

\section{DIVERGENCE AMONG MAJOR CLADES}

As uncertainty in calibrations can greatly affect estimates of rate variation and their interpretation (Ho \& Phillips, 2009; Smith, 2009; Smedmarket al., 2010), probabilistic calibration priors were used, which are more appropriate in dealing with uncertainty than point calibrations (Drummond et al., 2006). Moreover, a normally distributed prior was used on the ages of calibrated nodes, as it allows for a conservative bidirectional distribution of the uncertainty during the estimation (Ho \& Phillips, 2009).

The mean values reported in Table 2 are derived from calibrating nodes A, B and C (Fig. 3) using the values reported by Irestedt et al. (2009), including their $95 \%$ confidence intervals (CI), whereas the ranges correspond to the upper- and lower-bound confidence intervals reported by Irestedt et al. (2009). The means obtained by using the upper- and lowerbound confidence intervals should not be interpreted as confidence intervals themselves, but rather as extremely conservative estimates.

The results from the means obtained in the analyses using the upper- and lower-bound confidence intervals reported by Irestedt et al. (2009) as priors are highly congruent with the results from the $95 \%$ CIs for the reported mean (Table 2). This congruence suggests that the conservative estimation of the divergence dates is similar to the confidence intervals recovered when using the mean. Throughout the biogeographical discussion only the mean dates are used, as they represent the set of trees with the highest posterior density (Drummond $\&$ Rambaut, 2007), and as such the date with the highest posterior credibility. According to the results, the tribe Thripophagini diverged from the Synallaxini around 13.3 Mya (95\% CI 11.4-15.1 Mya; node 1, Fig. 3 ). The clade of Metopothrix and Xenerpestes diverged 11.2 Mya (95\% CI 9.3-13.1 Mya; node 2, Fig. 3), whereas the split between Siptornis striaticollis nortoni and the rest of the Thripophagini took place around 8.4 Mya (95\% CI 6.7-11.4 Mya; node 4, Fig. 3), and the split leading to C. gutturata and the rest of the clade took place around 5.8 Mya (95\% CI 4.5-7 Mya; node 5, Fig. 3). Roraima split from the rest of the tribe $\sim 5.6$ Mya $(95 \%$ CI 4.3-6.6 Mya; node 6, Fig. 3), while the next split gave origin to the Limnoctites + Thripophaga + Cranioleuca clade, around 5.1 Mya (95\% CI 4.1-5.3 Mya; node 8, Fig. 3). Within Cranioleuca the split between clade A and the rest of the genus occurred at 4.4 Mya (95\% CI 3.45.3 Mya; node 9, Fig. 3), clade B split from clades C + D around 3.4 Mya (95\% CI 2.7-4.2 Mya; node 11, Fig. 3), and clades C and D split around 2.8 Mya (95\% CI 2.23.5 Mya; node 14, Fig. 3).

\section{DISCUSSION}

\section{SPATIAL AND TEMPORAL PATTERNS OF DIVERSIFICATION}

The split between the tribes Synallaxini and Thripophagini took place at a time when the eastern Cordillera of the Central Andes was at about 30\% of its current elevation (Gregory-Wodzicki, 2000), whereas the northern Andes had only attained half of their present elevation by the middle to late Miocene (Graham, 2009). Thus, it may be inferred that the common ancestor of Thripophagini was distributed in the lowlands or low montane forests. Divergence between Xenerpestes and Metopothrix, the sister group to other thripophagines, took place 8.9 Mya. Metopothrix is distributed in the lowlands of the Napo area of endemism, whereas $X$. singularis is distributed along the eastern slope of the Andes of Ecuador and northern Peru, in the humid montane forest. The split between these two allopatric species coincides with active uplift of the northern Andes (Hoorn et al., 1995; Hooghiemstra et al., 2006; Graham, 2009), so their divergence might be related to this event. This uplift created new environments while at the same time creating ecological barriers altitudinally between newly isolated species. It is important to mention that 


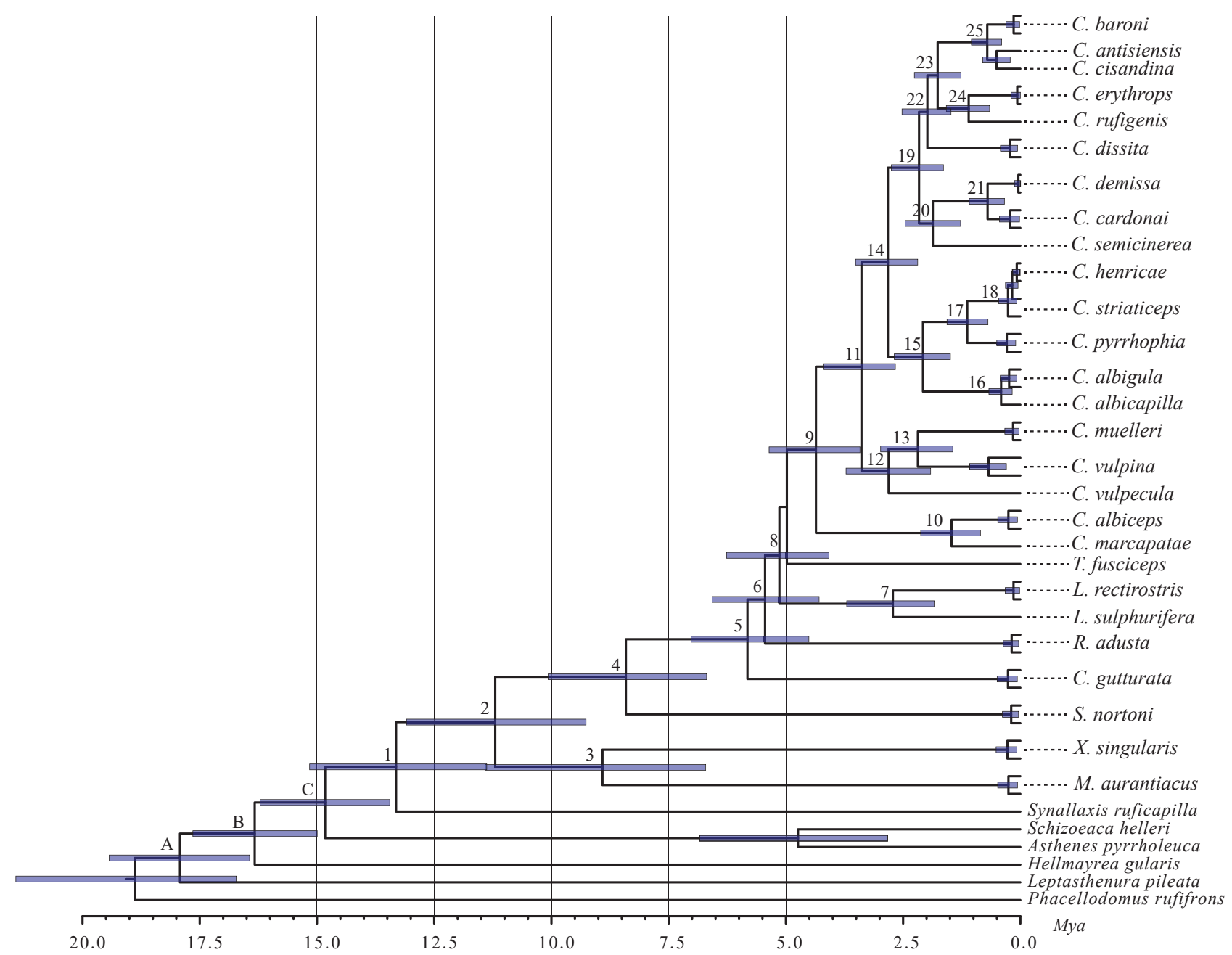

Figure 3. Estimated dates of divergence for species in the tribe Thripophagini, calculated by BEAST. Numbers above nodes correspond to those in Table 2. Purple horizontal bars depict confidence intervals.

although Xenerpestes has three recognized species, only one, $X$. singularis, was included in this analysis, so further studies are needed within this clade. The next clade to split was that of Siptornis straticollis nortoni, which is distributed along the east slope of the Andes of northern Peru. This split took place 8.4 Mya. Given its timing, it is possible that the origin of this deep lineage is also related to Andean uplift, so further studies are needed within this clade.

Roraima adusta is distributed in the Pantepui region. Reconstruction of the ancestral character-state for the node leading to $R$. adusta is equivocal. Cranioleuca gutturata is the sister group to the remainder of the thripophagines, including $R$. adusta, and is distributed in the tropical forest, varzea and tierra firme of the Amazon basin. Roraima adusta diverged around 5.4 Mya. Although some authors have suggested that the tepuis were recently colonized from the northern
Andes (Chapman, 1931; Mayr \& Phelps, 1967; Cook, 1974; Haffer, 1974), probably as a result of the climatic oscillations of the Pleistocene (Chapman, 1931; Cook, 1974; Haffer, 1974), others suggest that some species found in this region might have descended from taxa that at some point were more widespread across northern South America (Braun et al., 2005; Brumfield \& Edwards, 2007; Mauck \& Burns, 2009). In the case of $R$. adusta, its ancestor was probably distributed in the surrounding lowlands of the Pantepui. However, the process by which its ancestor was isolated from the lowlands to the Pantepui is not clear.

The split leading to the clade Limnoctites + Thripophaga + Cranioleuca took place $\sim 5.1$ Mya. Again, the reconstruction of the ancestral state of this node was equivocal. Moreover, because the phylogenetic relationships among these three genera are not resolved, it is not possible to make further 
biogeographical inferences of the events that gave rise to this group.

Within Cranioleuca, the split between clade A and the rest of the genus occurred at 4.4 Mya. Cranioleuca a. albiceps and C. m. marcapatae are distributed in the upper montane or Andean forest of Peru and Bolivia, respectively. However, the reconstruction of the ancestral character state leading to this clade is equivocal. Because the closest genera to Cranioleuca - Thripophaga and Limnoctites - are distributed in the lowlands, it can be inferred that the ancestor of Cranioleuca was also distributed in the lowlands. If this is so, a vicariance event due to uplift of the Andes could be the cause of this split, as the eastern Bolivian cordillera gained almost half of its current height in the last 6-10 Myr (Graham, 2009), and if the ancestor of Cranioleuca was distributed along the slopes of the Andes at lower altitudes, it could have been uplifted along with the Andes. Cranioleuca a. albiceps split from $C$. m. marcapatae between 1.2 and 1.9 Mya, with a mean of 1.5 Mya. These two species are separated by the Apurimac River Valley, and their divergence is more or less contemporary with that of the hummingbirds Schistes chapmani and S. geoffroyi ( 2.5 Mya; Quintero \& Perktas, 2017), and the parrots Hapalopsittaca melanotis melanotis and $H . m$. peruviana ( 1 Mya; Quintero et al., 2013), which have the same distribution and are divided by this same biogeographical barrier. The divergence of these three pairs of disjunct species at about the same time supports the hypothesis that vicariance of all three pairs may be associated with the formation of this valley, as redundant patterns are more likely to be caused by the same process than to independent processes such as dispersal in each of the three lineages.

Clade B is the only one within Cranioleuca that is composed entirely of Amazonian species. Cranioleuca muelleri inhabits varzea forests, $C$. vulpina is found in varzea forests, riverine forests and flooded savannah woodlands (Zimmer, 1997), and C. vulpecula is found in successional forests in islands of the Amazon river and its 'white-water tributaries' (Zimmer, 1997). This clade was isolated in Amazonia between 2.3 and 3.7 Mya, with a mean of around 2.8 Mya. Campbell et al. (2006) and Ribas et al., (2012) have suggested that this coincides with the establishment of the Amazon drainage.

Clades C and D split 2.8 Mya. As described by Vaurie (1980) and Garcia-Moreno et al. (1999), clade $\mathrm{C}$ includes southern species distributed in woodlands and dry forests, which construct nests supported from the bottom, whereas clade D contains northern species that are mainly distributed in the humid submontane forests (the exception being C. baroni, which is found in drier zones and higher habitats) and which construct pendant nests (Vaurie, 1980; Garcia-Moreno et al.,
1999). It is not clear what event or events isolated these two clades, and further analyses are needed.

Within clade $\mathrm{C}$, the divergence between C. p. pyrrhophia, C. p. striaticeps, C. henricae and C. obsoleta of the Austral Andes and the Pampas, and that between $C$. albicapilla and C. a. albigula from central and southern Peru, were initiated around 1.7 and 2.7 Mya, with a mean at 2.1 Mya. As in the case of C. m. marcapate/C. a. albiceps, the Andean species of the two subclades within clade $\mathrm{C}$ are divided by the Apurimac river valley, and their divergence is contemporary with that of the other pairs of species that share this distribution, such as the parrots $H$. m. melanotis and $H$. m. peruviana (Quintero et al., 2013), and the hummingbirds Schistes chapmani and S. geoffroyi (Quintero \& Perktas, 2017). Thus, the split between C. a. albicapilla + C. a. albigula and the clade including C. p. pyrrhophia, C. p. striaticeps, $C$. henricae and $C$. obsoleta serves as further evidence that the formation of biogeographical barriers, in this case the Apurimac river valley, is a major contributor to the isolation and diversification of these clades. The clade of C. p. pyrrhophia, C. p. striaticeps, C. henricae and C. obsoleta diverged around 1.1 Mya. Cranioleuca p. striaticeps is allopatric to C. p. pyrrhophia, with C. $p$. striaticeps found in the dry woodlands of the Bolivian Andes, and C. pyrrhophia distributed in the dry areas of the Chaco and the Pampas. Diversification of these latter two taxa may have been related to the shift of the montane vegetation during the glacial periods of the Pleistocene, when the upper montane forest descended to altitudes that correspond to the current montane and tropical lowland forest (Hooghiemstra et al., 2000). As dry vegetation is present within the distributions of both species, the descent of vegetation zones during glaciations may have created a dry corridor that allowed the common ancestor of this species to reach lower altitudes. During the interglacial this connection might have been lost, isolating C. p. striaticeps from C. p. pyrrophia. No biogeographical inferences regarding $C$. henricae and $C$. obsoleta can be drawn at this time, until their taxonomic status has been resolved. However, given that $C$. henricae is paraphyletic for mtDNA with respect to C. p. striaticeps, and the individuals of C. c. debilis are nested within $C$. henricae, this lends support to the idea that $C$. henricae could in fact be a hybrid. There is a need to conduct a detailed morphological and phylogeographical analysis of $C$. henricae to clarify its relationships.

Within group $\mathrm{D}$, the clade containing $C$. demissa cardonai, C.d.demissa and C. semicinerea diverged from the remainder of the clade between 1.7 and 2.8 Mya, with a mean of 2.2 Mya. The split between C. semicinerea of the dry Caatinga forest in eastern Brazil and $C$. $d$. cardonai and $C$. $d$. demissa of the humid montane forests of the 
Pantepui took place around 1.9 Mya. The divergence between these two clades may be related to vicariance due to the dry glacial intervals during the Pleistocene, which further isolated dry areas such as the Caatinga from the surrounding humid areas such as those of the Pantepui (Hooghiemstra et al., 2000). Once in the Pantepui, the ancestor of $C$. d. cardonai $+C$. d. demissa may have reached the montane forests of the tepuis during the cycles of vertical shifting of the montane forest belts of the glacial/interglacial periods (Rull, 2005). Further biogeographical studies are needed to understand the split between $C$. d. cardonai of the Gran Sabana, and C. d. demissa of the Duida. Cranioleuca dissita split from the rest of the clade $\sim 0.7$ Mya. Cranioleuca dissita is distributed on Isla Coiba, in the Veragua Archipelago of Panama. Coiba is part of a system of volcanic oceanic islands uplifted at the end of the Tertiary (Castroviejo \& Ibáñez, 2001). It is not clear what event may have caused the split of this taxon, and reconstruction of the ancestral character state is equivocal for this node. However, it is possible that a dispersal event may have been responsible. Finally, the next split divided the remainder of clade D into two groups: C. e. erythrops (western Ecuador) + C. e. rufigenis (Central America) from C. b. baroni, C. c. cisandina and C. a. antisiensis from the Andes. This split took place $\sim 1.8$ Mya. At present it is not possible to reconstruct the events that may have been responsible for the split of these two clades, as the rest of the species from the northern Andes are missing from the analysis. Cranioleuca e. erythrops from western Ecuador, and C. rufigenis from west Panama and Costa Rica diverged from each other 1.1 Mya, after the Isthmus of Panama was already in place (Coates et al., 1992). The clade that contains C. c. cisandina, C. a. antisiensis and C. b. baroni diverged $\sim 0.7 \mathrm{Mya}$, so each of the species within it is very recent (Fig. 3). Cranioleuca c. cisandina, C. a. antisiensis and $C . b$. baroni have allopatric distributions, with C. c. cisandina and C. a. antisiensis distributed in humid montane forests at lower altitudes than C. b. baroni, which in turn is found in dry upper montane or Andean forests. The reconstruction of the ancestral distributions suggests that the ancestor of this clade was distributed in southern Peru. The difference in habitat between the humid montane C. c. cisandina, C. $a$. antisiensis and the upper montane, drier C. b. baroni may be an indication that the split between these taxa may have been related to vegetation changes during the climatic oscillations of the Pleistocene (Hooghiemstra et al., 2000).

\section{CONCLUSIONS}

The broad sampling and the use of basal taxonomic units in this study allowed us to better understand the diversity and evolutionary relationships of this group of birds, as well as an indication of its complex biogeographical history. Our phylogenetic findings again highlight the importance of framing any evolutionary study within a phylogenetic context. Further phylogeographical studies are needed to establish the species limits within the complex formed by C. a. antisiensis, C. b. baroni and C. c. cisandina, as well as to clarify the species status of $C$. henricae. Further work will also clarify the status of several subspecies that we recovered as genetically distinct. It is important to take into account the limitations of the present analysis given the exclusive use of mitochondrial genes. Further studies should include more thorough sampling for this diverse and complex group, and include nuclear genes.

Our results indicate that the diversification of this group seems to have been influenced, at least in part, by the uplift of the Andes, the creation of new montane habitats and barriers, the evolution of Amazonian drainages and landscapes, and the climatic oscillations of the Pleistocene.

\section{ACKNOWLEDGMENTS}

We thank the ornithology collections from the following institutions for providing tissues for this study, without which this study would not have been possible: The Academy of Natural Sciences of Philadelphia, the Field Museum of Natural History, the National Museum of Natural History, Louisiana State University Museum of Natural Science, and the Natural History Museum of Denmark. E.Q. is grateful to Joel Cracraft, John Bates, Eleanor Sterling, Nancy Simmons and A. Townsend Peterson for making valuable comments and additions to earlier versions of the manuscript. We are very grateful to the two anonymous reviewers for their thorough reading and helpful comments. An earlier version of this paper was part of E.Q.'s doctoral dissertation. Research funding for E.Q.'s doctoral degree was provided by Fulbright, the OAS, the GSAS at Columbia University, the American Museum of Natural History Graduate Student Fellowship Program, CONACyT (145857), and the Frank. M. Chapman Memorial Fund of the American Museum of Natural History. Research funding for U.P. was provided by a Frank M. Chapman Postdoctoral Fellowship from the American Museum of Natural History. This paper is a contribution from the Monell Molecular Laboratory and the Cullman Research Facility of the Department of Ornithology, American Museum of Natural History, and has received generous support from the Lewis B. and Dorothy Cullman Program for Molecular Systematics Studies, a joint initiative of the New York Botanical Garden, the American Museum of Natural History and the Sackler Institute of Comparative Genomics. 


\section{REFERENCES}

Almeida FC, Bonvicino CR, Cordeiro-Estrela P. 2007. Phylogeny and temporal diversification of Calomys (Rodentia, Sigmodontinae): implications for the biogeography of an endemic genus of the open/dry biomes of South America. Molecular Phylogenetics and Evolution 42: 449-466.

Applied Biosystems. 2009. DNA sequencing by capillary electrophoresis. Applied biosystems chemistry guide, 2nd edn. Foster City, Applied Biosystems.

Bates JM, Zink RM. 1994. Evolution into the Andes: molecular evidence for species relationships in the genus Leptopogon. Auk 111: 507-515.

Belton W. 1985. Birds of Rio Grande do Sul, Brazil, part 1. Rheidae through Furnariidae. Bulletin of the American Museum of Natural History 178: 369-636.

Bleiweiss R. 1998. Tempo and mode of hummingbird evolution. Biological Journal of the Linnean Society 65: 63-67.

Braun MJ, Isler ML, Isler PR, Bates JM, Robbins MB. 2005. Avian speciation in the Pantepui: the case of the Roraiman antbird (Percnostola [Schistocichla] "Leucostigma" Saturata). Condor 107: 327-341.

Brumfield RT, Edwards SV. 2007. Evolution into and out of the Andes: a Bayesian analysis of historical diversification in Thamnophilus antshrikes. Evolution 61: 346-367.

Cadena CD, Klicka J, Ricklefs RE. 2007. Evolutionary differentiation in the Neotropical montane region: molecular phylogenetics and phylogeography of Buarremon brushfinches (Aves, Emberizidae). Molecular Phylogenetics and Evolution 44: 993-1016.

Campbell KE Jr, Frailey CD, Romero-Pittman L. 2006. The Pan-Amazonian Ucayali Peneplain, late Neogene sedimentation in Amazonia, and the birth of the modern Amazon River system. Palaeogeography, Palaeoclimatology, Palaeoecology 239: 166-219.

Castroviejo S, Ibáñez A. 2001. Origen y análisis de la diversidad biológica de la isla de Coiba. Quercus 188: 29-32.

Ceccarelli FS, Ojanguren-Affilastro A, Ramírez MJ, Ochoa JA, Mattoni CI, Prendini L. 2016. Andean uplift drives diversification of the bothriurid scorpion genus Brachistosternus. Journal of Biogeography 43: 942-1954.

Chapman FM. 1931. The upper zonal bird-life of Mts. Roraima and Duida. Bulletin of the American Museum of Natural History 63: 1-135.

Chaves JA, Pollinger JP, Smith TB, LeBuhn G. 2007. The role of geography and ecology in shaping the phylogeography of the speckled hummingbird (Adelomyia melanogenys) in Ecuador. Molecular Phylogenetics and Evolution 43: 795-807.

Chesser RT. 2004. Systematics, evolution, and biogeography of the South American ovenbird genus Cinclodes. Auk 121: $752-766$.

Claramunt S. 2002. Variación geográfica en Cranioleuca pyrrhophya y el límite con Cranioleuca obsoleta (Furnariidae). Ornitologia Neotropical 13: 255-266.

Claramunt S. 2010. Discovering exceptional diversifications at continental scales: the case of the endemic families of neotropical suboscine passerines. Evolution 64: 2004-2019.
Coates AG, Jackson JBC, Collins LS, Cronin TM, Dowsett HJ, Bybell LM, Jung P, Obando JA. 1992. Closure of the Isthmus of Panama - the near-shore marine record of Costa-Rica and western Panama. Geological Society of America Bulletin 104: 814-828.

Cook RE. 1974. Origin of the highland avifauna of Southern Venezuela. Systematic Zoology 23: 257-264.

Cory CB, Hellmayr CE. 1925. Catalogue of birds of the Americas. Field Museum of Natural History Zoological Series 234: part IV.

Cracraft J. 1985. Historical biogeography and patterns of differentiation within the South American avifauna: areas of endemism. American Ornithologist Union Monographs 36: 49-84.

Cracraft J. 1997. Species concepts in systematics and conservation biology. An ornithological viewpoint. In: Claridge MF, Dawah HA, Wilson MR, eds. Species, the units of biodiversity. London: Chapman and Hall, 325-339.

Derryberry EP, Claramunt S, Derryberry G, Chesser RT, Cracraft J, Aleixo A, Pérez-Emán J, Remsen JV Jr, Brumfield RT. 2011. Lineage diversification and morphological evolution in a large-scale continental radiation: the neotropical ovenbirds and woodcreepers (Aves: Furnariidae). Evolution 65: 2973-2986.

Drummond AJ, Ho SYW, Phillips MJ, Rambaut A. 2006. Relaxed phylogenetics and dating with confidence. PLoS Biology 4: e88. Available at: https://doi.org/10.1371/journal. pbio. 0040088

Drummond AJ, Rambaut A. 2007. BEAST: Bayesian evolutionary analysis by sampling trees. BMC Evolutionary Biology 7: 214.

Ericson PGP, Irestedt M, Johansson US. 2003. Evolution, biogeography, and patterns of diversification in passerine birds. Journal of Avian Biology 34: 3-15.

Ericson PG, Johansson US. 2003. Phylogeny of Passerida (Aves: Passeriformes) based on nuclear and mitochondrial sequence data. Molecular Phylogenetics and Evolution 29: 126-138.

Farris JS, Kallersjo M, Kluge AG, Bult C. 1995. Testing significance of incongruence. Cladistics 10: 315-319.

Felsenstein J. 1985. Confidence limits on phylogenies: an approach using the bootstrap. Evolution 39: 783-791.

Fjeldsa J, Krabbe N. 1990. Birds of the high Andes. Copenhagen: Zoological Museum, University of Copenhagen and Apollo Books.

García-Moreno J, Arctander P, Fjeldså J. 1999. A case of rapid diversification in the neotropics: phylogenetic relationships among Cranioleuca spinetails (Aves, Furnariidae). Molecular Phylogenetics and Evolution 12: 273-281.

Graham A. 2009. The Andes: a geological overview from a biological perspective. Annals of the Missouri Botanical Garden 96: 371-385.

Gregory-Wodzicki KM. 2000. Uplift history of the central and northern Andes: a review. Geological Society of American Bulletin 112: 1091-1105.

Hackett SJ, Kimball RT, Reddy S, Bowie RC, Braun EL, Braun MJ, Chojnowski JL, Cox WA, Han KL, Harshman J, Huddleston CJ, Marks BD, Miglia KJ, 
Moore WS, Sheldon FH, Steadman DW, Witt CC, Yuri T. 2008. A phylogenomic study of birds reveals their evolutionary history. Science 320: 1763-1768.

Haffer J. 1974. Avian speciation in tropical America. Cambridge: Nuttall Ornithological Club.

Ho SY, Phillips MJ. 2009. Accounting for calibration uncertainty in phylogenetic estimation of evolutionary divergence times. Systematic Biology 58: 367-380.

Hooghiemstra H, Van Der Hammen T. 1998. Neogene and Quaternary development of the Neotropical rain forest: the forest refugia hypothesis, and a literature review. EarthScience Reviews 44: 147-183.

Hooghiemstra H, Van Der Hammen T, Cleef A. 2000. Evolution of forests in the northern Andes and Amazonian lowlands during the tertiary and quaternary. In: Guariguata M, ed. Ecology of neotropical rain forests. Wageningen: Wageningen University.

Hooghiemstra H, Wijninga VM, Cleef AM. 2006. The paleobotanical record of Colombia: implications for biogeography and biodiversity. Annals of the Missouri Botanical Garden 93: 297-324.

Hoorn C, Guerrero J, Sarmiento GA, Lorente MA. 1995. Andean tectonics as a cause for changing drainage patterns in Miocene northern South America. Geology 23: 237-240.

Hoorn C, Wesselingh FP, ter Steege H, Bermudez MA, Mora A, Sevink J, Sanmartín I, Sanchez-Meseguer A, Anderson CL, Figueiredo JP, Jaramillo C, Riff D, Negri FR, Hooghiemstra H, Lundberg J, Stadler T, Särkinen T, Antonelli A. 2010. Amazonia through time: Andean uplift, climate change, landscape evolution, and biodiversity. Science 330: 927-931.

del Hoyo J, Collar NJ. 2016. $H B W$ and birdlife international illustrated checklist of the birds of the world, Vol, 2. Barcelona: Lynx Edicions.

del Hoyo J, Elliott A, Sargatal J, Christie DA, Kirwan G, eds. 2019. Handbook of the birds of the world alive. Barcelona: Lynx Edicions. Available at http://www.hbw.com/ (February 2019).

Huelsenbeck JP, Ronquist F. 2001. MRBAYES: bayesian inference of phylogenetic trees. Bioinformatics 17: 754-755.

Irestedt M, Fjeldså J, Dalén L, Ericson PG. 2009. Convergent evolution, habitat shifts and variable diversification rates in the ovenbird-woodcreeper family (Furnariidae). BMC Evolutionary Biology 9: 268.

Irestedt M, Fjeldså J, Johansson US, Ericson PG. 2002. Systematic relationships and biogeography of the tracheophone suboscines (Aves: Passeriformes). Molecular Phylogenetics and Evolution 23: 499-512.

Irestedt M, Johansson US, Parsons TJ, Ericson PGP. 2001. Phylogeny of major lineages of suboscines (Passeriformes) analysed by nuclear DNA sequence data. Journal of Avian Biology 32: 15-25.

Koepcke M. 1961a. Las razas geográficas de Cranioleuca antisiensis. Publicaciones del Museo de Historia Natural “Javier Prado”, Serie A Zoologia 20: 1-17.

Koepcke M. 1961b. Birds of the western slope of the Andes of Peru. American Museum Novitates 2028: 1-31.
Lutz HL, Weckstein JD, Patané JS, Bates JM, Aleixo A. 2013. Biogeography and spatio-temporal diversification of Selenidera and Andigena toucans (Aves: Ramphastidae). Molecular Phylogenetics and Evolution 69: 873-883.

Maijer S, Fjeldsa J. 1997. Description of a new Cranioleuca spinetail from Bolivia and a "leapfrog pattern" of geographic variation in the genus. Ibis 139: 607-616.

Mauck WM, Burns KJ. 2009. Phylogeny, biogeography, and recurrent evolution of divergent bill types in the nectarstealing flowerpiercers (Thraupini: Diglossa and Diglossopis). Biological Journal of the Linnean Society 98: 14-28.

Mayr E, Phelps, WHJ. 1967. The origin of the bird fauna of the southern Venezuelan highlands. Bulletin of the American Museum of Natural History 136: 273-327.

Meyer De Schauensee R. 1970. A guide to the birds of South America. Wynnwood: Livingston Publishing Co.

Miller M, Holder M, Vos R, Midford P, Liebowitz T, Chan L, Hoover P, Warnow T. 2010. The CIPRES portals. Available at: http://www.phylo.org/sub_sections/portal.

Moyle RG, Chesser RT, Brumfield RT, Tello JG, Marchese DJ, Cracraft J. 2009. Phylogeny and phylogenetic classification of the antbirds, ovenbirds, woodcreepers, and allies (Aves: Passeriformes: infraorder Furnariides). Cladistics 25: 386-405.

Neill DA. 1999. Vegetation. In: Jørgensen PM, León-Yánez S, eds. Catalogue of the vascular plants of Ecuador. St Louis: Missouri Botanical Garden.

Nixon KC. 1999. The parsimony ratchet, a new method for rapid parsimony analysis. Cladistics 15: 407-414.

Nylander, JAA. 2004. MrModeltest $v$ 2.3. Program distributed by the author. Uppsala: Evolutionary Biology Centre, Uppsala University.

Olson SL, Irestedt M, Ericson PGP, Fjeldsa J. 2005. Independent evolution of two darwinian marsh-dwelling ovenbirds (Furnariidae: Limnornis, Limnoctites). Ornitologia Neotropical 16: 347-359.

Pérez-Emán JL. 2005. Molecular phylogenetics and biogeography of the Neotropical redstarts (Myioborus; Aves, Parulinae). Molecular Phylogenetics and Evolution 37: 511-528.

Peters JL. 1951. Check-list of birds of the World, Vol. 7. Cambridge: Museum of Comparative Zoology, Harvard University.

Phelps WH Jr, Dickerman RW. 1980. Cuatro subespecies nuevas de Aves (Furmariidae, Formicariidae) de la región de Pantepui, estado de Bolivar y territorio Amazonas, Venezuela. Boletín de la Sociedad Venezolana de Ciencias Naturales, 33: 139-147.

Quintero E, Perktas U. 2017. Phylogeny and biogeography of a subclade of mangoes (Aves, Trochilidae). Journal of Ornithology 159: 29-46.

Quintero E, Ribas CC, Cracraft J. 2013. The Andean Hapalopsittaca parrots (Psittacidae, Aves): an example of montane-tropical lowland vicariance. Zoologica Scripta 42: $28-43$.

Rambaut A. 2009. FigTree, version 1.3.1. Available at: http:// tree.bio.ed.ac.uk/software/figtree/ 
Remsen JV. 1984. Geographic-variation, zoogeography, and possible rapid evolution in some Cranioleuca spinetails (Furnariidae) of the Andes. Wilson Bulletin 96: 515-523.

Remsen JV. 2003. Family Furnariidae (ovenbirds). In: Del Hoyo J, Elliot A, Christie D, eds. Handbook of the Birds of the World. Broadbills to Tapaculos. Barcelona: Lynx Edicions.

Remsen JV Jr, Areta JI, Cadena CD, Claramunt S, Jaramillo A, Pacheco JF, Robbins MB, Stiles FG, Stotz DF, Zimmer KJ. 2018. A classification of the bird species of South America. American Ornithologists' Union. Available at: http://www.museum.lsu.edu/ Remsen/ SACCBaseline.htm

Ribas CC, Aleixo A, Miyaki CY, Cracraft J. 2012. A paleobiogeographic model for biotic diversification within Amazonia. Proceedings of the Royal Society B 279: 681-689.

Ribas CC, Moyle RG, Miyaki CY, Cracraft J. 2007. Deciphering the origins of montane biotas: linking Andean tectonics and climatic oscillations to independent regimes of diversification in Pionus parrots. Proceedings of the Royal Society B 274: 2399-2408.

Ridgely RS, Tudor G. 1994. The birds of South America. Austin: University of Texas Press.

Rull V. 2005. Biotic diversification in the Guayana highlands: a proposal. Journal of Biogeography 32: 921-927.

Sibley CG, Ahlquist JE. 1985. Phylogeny and classification of New World suboscine passerine birds (Passeriformes: Oligomyodi: Tyrannides). Ornithological Monographs 36: 396-430.
Sibley CG, Ahlquist JE. 1990. Phylogeny and classification of birds. New Haven: Yale University Press.

Smedmark JEE, Eriksson T, Bremer B. 2010. Divergence time uncertainty and historical biogeography reconstruction - an example from Urophylleae (Rubiaceae). Journal of Biogeography 37: 2260-2274.

Smith SA. 2009. Taking into account phylogenetic and divergence-time uncertainty in a parametric biogeographical analysis of the Northern Hemisphere plant clade Caprifolieae. Journal of Biogeography 36: 2324-2337.

Sorenson MD, Ast JC, Dimcheff DE, Yuri T, Mindell DP. 1999. Primers for a PCR-based approach to mitochondrial genome sequencing in birds and other vertebrates. Molecular Phylogenetics and Evolution 12: 105-114.

Swofford DL. 2002. PAUP*: Phylogenetic analysis using parsimony (*and other methods). Version 4.0b10. Sunderland: Sinauer.

Vaurie C. 1980. Taxonomy and geographical distribution of the Furnariidae (Aves, Passeriformes). Bulletin of the American Museum of Natural History 166: 1-357.

Wetmore A. 1957. The birds of Isla Coiba, Panamá. Washington: Smithsonian Institution.

Zimmer KJ. 1997. Species limits in Cranioleuca vulpina. Ornithological Monographs 48: 849-864.

Zwickl DJ. 2006. Genetic algorithm approaches for the phylogenetic analysis of large biological sequence datasets under the maximum likelihood criterion. Unpublished $\mathrm{PhD}$ Dissertation, The University of Texas at Austin. 